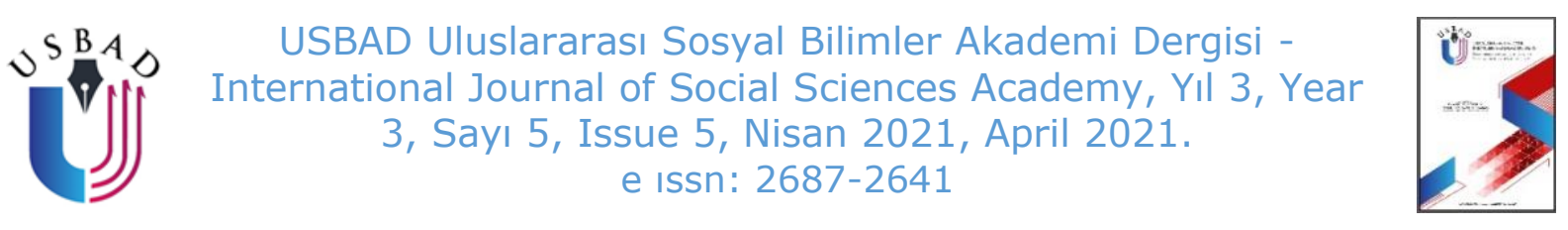

\title{
CUMHURİYET DÖNEMİ KOZAN (ADANA) İLÇESİNİN NÜFUS COĞRAFYASI
}

\author{
POPULATION GEOGRAPHY OF THE DISTRICT OF KOZAN (ADANA) IN \\ THE REPUBLIC IN REPUBLIC PERIOD
}

\author{
Güven ŞAHíN \\ Dr., İstanbul Üniversitesi Sosyal Bilimler \\ Enstitüsü, Coğrafya ABD., \\ İstanbul / Türkiye \\ Phd., İstanbul University Institute of \\ Social Sciences, Department of \\ Geography, İstanbul / Türkiye \\ guven.sahin@ogr.iu.edu.tr
}

ORCID ID: 0000-0002-5054-3711

\author{
Çağatay AKYOL \\ Çukurova Üniversitesi Eğitim Fakültesi \\ Temel Eğitim Bölümü \\ Adana / Türkiye \\ PhD., Çukurova University Education \\ Faculty, Department of Primary \\ Education, Adana / Türkiye \\ cakyol99@cu.edu.tr
}

ORCID ID: 0000-0002-5912-8637

\author{
Makale bilgisi | Article Information \\ DOI: $10.47994 /$ usbad.826039 \\ Makale Türü / Article Type: Araştırma Makalesi / Research Article \\ Geliş Tarihi / Date Received: 14.11.2020 \\ Kabul Tarihi / Date Accepted: 04.02.2021 \\ Yayın Tarihi / Date Published: 20.04.2021 \\ Yayın Sezonu / Pub Date Season: Nisan / April
}

Bu Makaleye Atıf İçin / To Cite This Article: Şahin, G. \& Akyol, C.. (2021). Cumhuriyet Dönemi Kozan (Adana) İlçesinin Nüfus Coğrafyası. USBAD Uluslararası Sosyal Bilimler Akademi Dergisi 3(5), 104-159.

İntihal: Bu makale intihal.net yazılımınca taranmıştır. İntihal tespit edilmemiştir. Plagiarism: This article has been scanned by intihal.net. No plagiarism detected.

\section{intihal.net}

İletişim: Web: https://dergipark.org.tr/tr/pub/usbad mail: usbaddergi@gmail.com 
Öz: Kozan; konumu, topografik, hidrografik ve klimatik özellikleriyle Bereketli Hilal'in (Fertile Crescent) bir parçası olmuş ve buna bağlı olarak da medeniyet tarihi binlerce yılı aşan önemli bir yerleşim birimi olmuştur. Tarihin pek çok döneminde siyasi, dini, askeri ve iktisadi önemini korumayı başarmış olan Kozan'ın sadece Türkiye açısından değil dünya medeniyet tarihi açısından da çok özel bir merkez olduğunun altı çizilmelidir. Cumhuriyet Devri'ne kadar "Sis" adıyla bilinen Kozan, günümüzde büyük ölçüde bitkisel üretim içerisinde turunçgiller başta olmak üzere bahçecilik, hayvancılık ve ormancılık ile geçimini sağlayan, küçük ve orta ölçekli sınırlı bir sanayisi bulunan bir ilçedir. Nüfus özellikleri bakımından incelediğimiz Kozan'da 1927 - 1985 ile 1990 2019 yılları arasında değerlendirebileceğimiz 2 dönem söz konusudur. İlçede 1927 'den sonra nüfus 1985 'e değin düzenli ve hızlı bir şekilde artıyorken, sonrasında (İmamoğlu'nun ayrılmasını takiben) ilçe nüfusu çok daha yavaş bir hızla artış göstermeye başlamıştır. Yapısal özellikleri açısından ise nüfusun cinsiyet, medeni durum, istihdam, eğitim seviyesi, hareketlilik durumu gibi hususlarının da ele alındığı bu çalışmada Kozan'ın tüm göstergeleriyle nüfus analizi yapılmıştır.

Anahtar Kelimeler: Kozan, Sis, Nüfus Coğrafyası, Demografi, Adana

Abstract: Kozan has become a part of the Fertile Crescent with its location, topographic, hydrographic and climatic features, and accordingly, it has been an important settlement whose history of civilization exceeds thousands of years. It should be underlined that Kozan, which has managed to preserve its political, religious, military, and economic importance in many periods of history, is a very special center not only from the point of Turkey but also from the history of world civilization. Known as "Sis" until the Republic Period, Kozan is today a district with a limited small and medium-sized industry that provides its living particularly with citrus fruits, horticulture, animal husbandry, and forestry largely in vegetative production. In Kozan, which we examined in terms of population characteristics, there are two periods that we can evaluate between $1927-1985$ and $1990-2019$. While the population in the district was increasing regularly and rapidly until 1985 after 1927, (following the departure of İmamoğlu) the population of the district started to increase at a much slower rate. In this study, in which issues such as gender, marital status, employment, education level, mobility of the population are also discussed in terms of structural features, population analysis has been made with all the indicators of Kozan.

Keywords: Kozan, Sis, Population Geography, Demography, Adana

\section{GİRİ̧}

Kozan, coğrafi konumu ve buna bağlı tabii özellikleriyle medeniyet tarihi boyunca önemini korumuş ve ele geçirilmeye çalışılmıştır. Günümüzde bu köklü medeniyet geçmişinin emarelerini 
çoğu yerde görmenin mümkün olduğu ilçe, sahip olduğu bu kültür mirasıyla ayrıca incelenmeye değer bir sahadır. En iyimser tahminlerle 4000 - 4500 yıllık bir medeniyet geçmişi bulunan Kozan'da, yapılan çalışmalar ve güncel literatür ışığında mazisinin daha da gerilere uzanabilecek olduğu kimi araştırmacılarca da dile getirilmiştir. Türklerin, Ermenilerin, Moğolların, Arapların, Rumların, Makedonların, Perslerin belli dönemlerde damgalarını vurmuş oldukları Kozan, bu özelliğinden ötürü gözde bir yer olması kadar bunun dezavantajlarının da yaşandığı bir yer olmuştur. Sık sık istilalara uğramış, zaman zaman büyük yağma olaylarına sahne olmuş ilçede, yerel aşiretlerin taşkınlıkları ve otorite boşluğundan ötürü de ciddi kargaşalar yaşanmıştır. Öte yandan Kozan ilçe merkezini oluşturan ve geçmişte Sis adıyla bilinen Merkez, görece önemli bir ticaret merkeziydi. Örneğin; 1572 tarihli Sis'in mufassal tahrir defterine göre; küçük dükkanlar, boyahane, sırça dükkanları, debbağhane, dokuma tezgahları ve mezbahalar bulunduğu gibi bunlardan başka hayvan ve köle pazarı, hububat pazarı, pamuk ve iplik pazarının da bulunuyordu (İdikurt, 2011: 35). Sahanın Suriye - Anadolu arasındaki ticaret yolu üzerindeki önemli duraklardan biri olması da buranın hareketliliğini artıran bir diğer faktör olmuştur.

İlçenin coğrafi şartları da buranın iskan, imar ve nüfus hareketleri üzerinde büyük ölçüde belirleyici olmuştur. Karakteristik Akdeniz ikliminin hakim olduğu Kozan'da, bataklıkların varlığı ve her yaz şiddetini artıran sıtma salgını gibi faktörler, burada uzun bir süre geniş nüfus kitlelerinin konar - göçer bir hayat sürmesine neden olmuştur. Öyle ki, yörenin ileri gelenleri dahi, yazları yaylalara çıkmakta, ancak havalar soğumaya başlayınca ovalık sahaya dönmekteydiler. Osmanlı İmparatorluğu'nun son yılları ile Cumhuriyet Dönemi'nin ilk yıllarında ise bataklıkların kurutulması, konar-göçerlerin yerleşik hayata teşviki, narenciye tarımının yaygınlaştırılması gibi unsurlar Kozan'ın günümüzdeki sosyo-ekonomik yapısını kazanmasında büyük rol oynamıştır.

Bu çalışmada; Adana gibi iktisadi bakımdan Türkiye'nin önemli merkezlerinden birinin yüzölçümü açısından 1., nüfus miktarı açısından ise 6. sırada yer alan Kozan ilçesi, nüfus coğrafyası özelinde irdelenmiştir. Çalışmada ilçenin toplam nüfus miktarı Osmanlı İmparatorluğu'nun son dönemi ile tüm Cumhuriyet Dönemi'ni kapsayacak şekilde ele alınmıştır. Bu kapsamda nüfusun cinsiyet yapısı ve medeni durumu, şehir ve kır nüfusları, eğitim durumu, nüfus 
yoğunlukları, coğrafi dağılım ve Adana ölçeğinde Kozan nüfusunun türlü açılardan yeri incelenmiştir. Buna göre de ilerleyen yıllarda demografik açıdan ortaya çıkabilecek durumlar, alınması gereken tedbirler, izlenebilecek yerel politikalar hakkında çıkarımlarda bulunulmuştur.

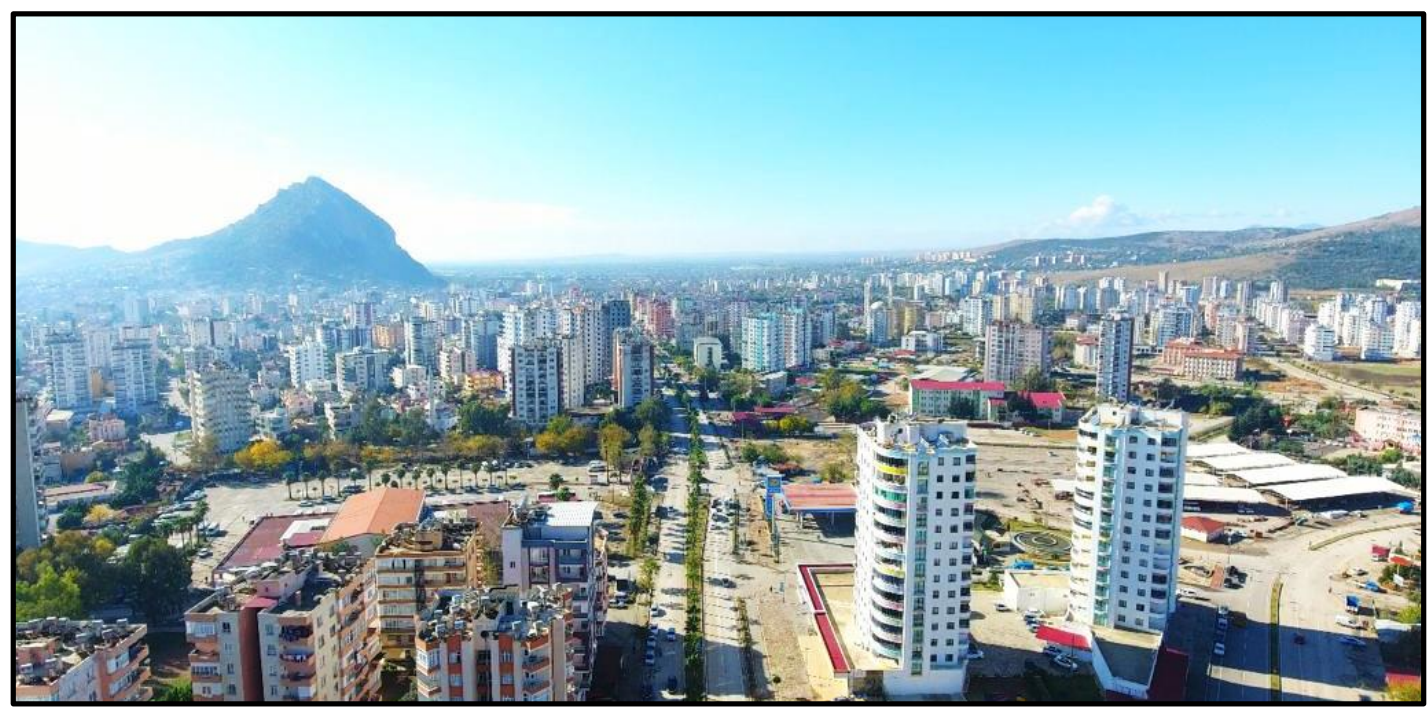

Fotoğraf 1: Kozan Şehir Merkezinden Görünüm / Çok Katlı Yoğun Yapılaşma Dikkat Çekici Ölçüde Gelişme Göstermiştir

Nüfus Coğrafyası çalışmalarında karşılaşılan en önemli sorunlar arasında yer alan sayımdan sayıma değişiklik gösterebilen, sorgulanan parametrelerin süreksizliğidir. Nitekim bu çalışmada da Kozan için etnik yapı, istihdam, ana dil, intihar sayıları gibi değişkenler süreklilik göstermediğinden sağıılı çıkarımlar yapabilmek mümkün olamamıştır. Öte yandan bazı parametreler ise sadece kapsadığı dönemi içine alacak şekilde incelenmiştir. Örneğin; Adana'nın büyükşehir olmasını takiben kırsal nüfus miktarlarının 0 (sıfır) kabul edilmesi nedeniyle, sadece kırsal nüfus miktarlarının derlendiği yıllar ele alınmıştır. Nüfus ile ilgili Türkiye İstatistik Kurumu (TÜİK) tarafından artık derlenmeyen veriler ise doğrudan ilgili kuruluşlardan elde edilmiş, bu kapsamda da Kozan İlçe Tarım ve Orman Müdürlüğü, İlçe Milli Eğitim Müdürlüğü, Kozan Sosyal Güvenlik Merkez Müdürlüğü ve Kozan Kaymakamlığı'ndan temin edilmiştir.

\section{TARİHSEL SÜREÇTE KOZAN}

Kozan, konumu itibariyle çok köklü bir medeniyet geçmişi bulunan sahanın bir parçasıdır. Tarihsel süreçte pek çok medeniyet kurulan bu saha, diğer çok sayıda medeniyetin de stratejik güzergâhlarından biri olmuştur. Kozan ve çevresinin özellikle yüksek 
verimli arazilerle kaplı oluşu, zengin orman kaynakları burayı çoğu medeniyetin gözdesi konumuna getirmiştir. Geçmişte "Sis", "Sisium", "Siski" ve "Sision" isimleriyle anılmış olan Kozan, Kilikya Krallığı (Kilikya Ermeni Krallığı)'na da başkentlik etmiştir (Darkot, 1993: 708; Aydın, 2019: 20). Kozan'ın geçmişteki adı olan ve Cumhuriyeti'in ilk yıllarına değin kullanılmış olan "Sis" adı ilk kez Asur kaynaklarında İdrimi kitabesinde "Zise" ile aynı olduğu tahmin edilen "Sizzu/ Sissu" şeklinde geçmektedir (Ünal ve Girginer, 2007: 201; Buyruk, 2011: 14). Asur kaynağında geçen Sissu zaman içerisinde Sis şeklini alarak bugünkü Kozan ve çevresini ifade eder manada kullanılmıştır. Bununla birlikte "Sis" adının kaynağı ile ilgili başka bir yaklaşım da Asurice "Kasis" kelimesinden önce "Asis"e daha sonraları da "Sis"e dönüştüğü yönündedir. Bundan başka Sis'in, Hititler zamanında Siyam, Romalılar zamanında ise Sisiyon/Sision olarak da anıldığı kaynaklarda geçmektedir (Buyruk, 2011: 15).

Kozan'ın medeniyet tarihine bakıldığında tahmini M.Ö. 2500 2300 olmakla birlikte M.Ö. 2000 ila 1400 arasında kurulmuş olan Luviler (Luvi Krallığı) bölgede hüküm sürmüş ilk medeniyetlerden olup söz konusu kavim için Anadolu'nun en eski halklarından olduğu da söylenmektedir (Zangger ve Mutlu, 2016: 1055). Bundan hareketle de Kozan ve çevresi için kabaca 4000 ila 4500 yıllık bir yerleşim geçmişi bulunduğunu söylemek mümkündür. Sonraları Kizzuvatna Krallığı, Hititler, Müslüman kavim ve devletlerin hakim olduğu Kozan'ın da dahil olduğu bölge, stratejik önemini yakın yıllara değin koruyarak gelmiştir. Gerçekten de henüz Orta Çağ başlarında bugünkü Kozan olan Sis için müstahkem bir hudut şehri olduğu kaynaklarda geçmektedir (Darkot, 1993: 708). Nitekim Memluk Devleti'nin kuzey sınırını da oluşturması hasebiyle Sis, hem stratejik açıdan çok önemli bir nokta olmuş hem de sık sık istilalara uğramıştır. Memlukler uzun süre Sis ve yakın çevresini de doğrudan kontrolleri altında tutmuşlardır (İdikurt, 2011: 30). Fakat sonraları özellikle Mısırlılar ile Moğolların saldırıları sonucu Sis büyük ölçüde tahribata uğramıştır (Darkot, 1993: 709). Kozan ve çevresi kısa bir süre de (21 yıl) Makedonya hakimiyetinde kalmıştır (Ertunç, 1991: 19). Kozan'ın Anadolu ve Suriye arasındaki tarihi ticaret yolu üzerinde bulunuyor olması da burayı ayrıca önemli bir merkez haline getirmiştir. Tarihte sahaya hakim olmuş pek çok medeniyet bölgede meşhur ve mamur Viranşehir, Tarsus, Mallos (Mallus), Ayas, Misis, Yılanlıkale, Toprakkale, Anavarza (Anazarva), Kozan, Payas, Karatepe, Arslantaş gibi şehirler meydana getirmişlerdir (Göney, 1976: 95). Bu durum bize 
sahanın hem iskan tarihinin köklülüğü hem de yoğun nüfus hareketlerine sahne olduğuna dair önemli kanıtlar sağlamaktadır.

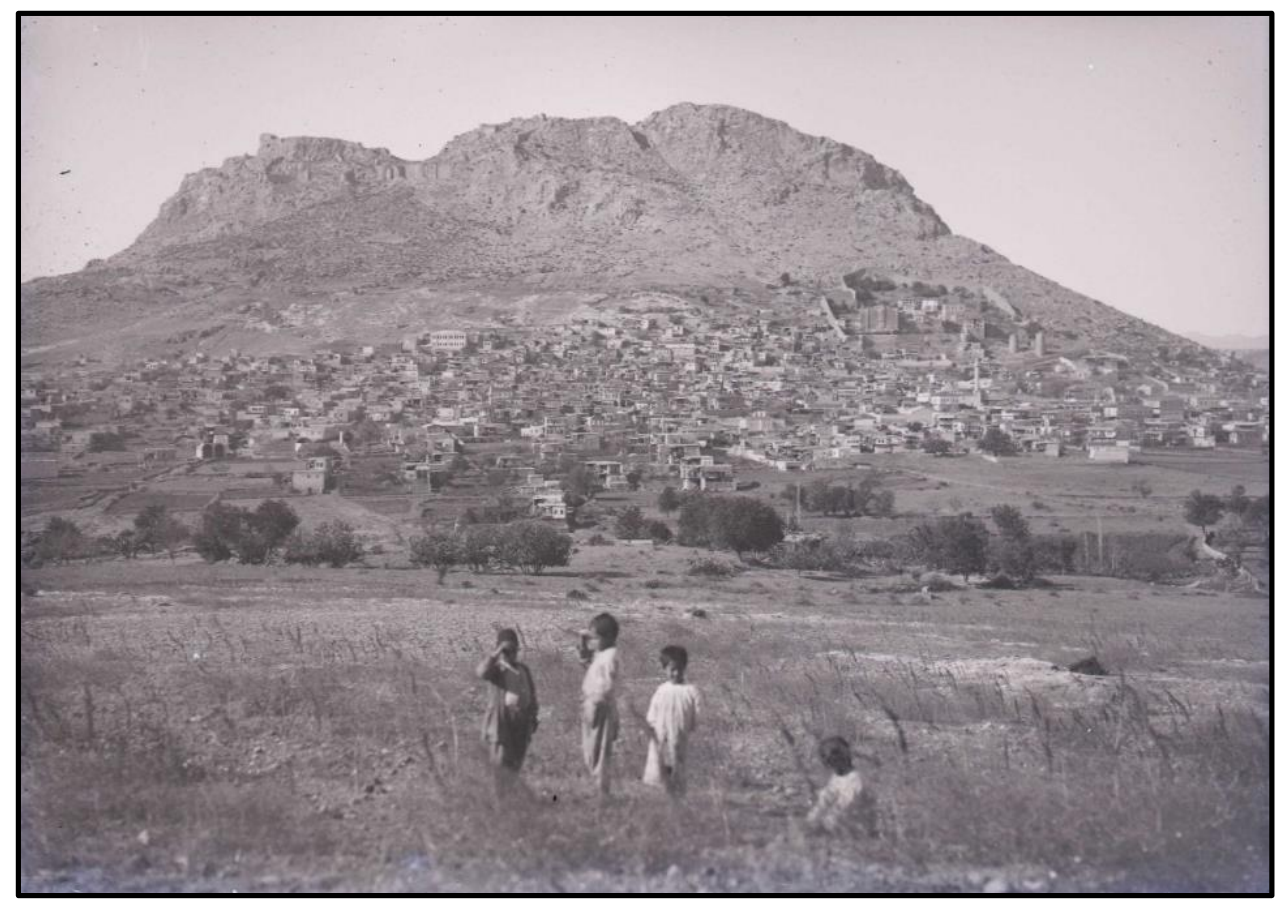

Fotoğraf 2: 1900'lerin Başlarında Kozan (Sis)'dan Genel Bir Görünüm (Archives departementales de L'Eure / Fransa)

Kozan, başka bir ifadeyle eski kaynaklardaki adıyla Sis'in Kilikya Ermeni Krallığı döneminde Kral II. Levon (1236? - 1289) tarafından başkent haline getirilmesiyle burada bir dizi imar faaliyetlerine girişilmiştir (Darkot, 1993: 709). Bununla birlikte Oldenburglu Wilbrand (Wilbrand von Oldenburg / 1180? - 1233), Kral II. Levon'un hükümdarlığından önce yaşamış olup kaleme almış olduğu eserinde Sis ile ilgili olarak, "Burası kralın payitahtı olup nüfusu çok sayıda ve zengindir; şehrin surları yok idi; burada bir Ermeni başpiskoposu ve Rum patriği oturuyordu" şeklinde bilgiler vermektedir (akt. Darkot, 1993: 709). Buradan da anlaşıldığı üzere Kozan çok daha önce başkent haline gelmiştir. Saha, 630'lardan itibaren Arap istilalarına uğramaya başlamıştır (Ertunç, 1991: 21). Yörede henüz 1200'lere gelmeden, 1187 yılında 5.000 kişilik bir Türkmen kitle tarafından Maraş üzerinden akınlara başlamış ve Adana ile Tarsus'u zapt etmiştir. Bu istilanın sonunda Ermeni Krallığı'nın elinde Sis ve Anazarba kalmıştır (Sümer, 1963: 4; İdikurt, 2011: 29). Türkler her ne kadar başlangıçta Sis'i ele geçirememişlerse de genel olarak bugünkü Adana, Osmaniye ve Kahramanmaraş, Türklerin iskanına açılmaya başlamıştır. Abbasiler zamanında bir uç beyliği olan sahaya da yine Türkler getirilerek burada 
iskan ettirilmişlerdir (Sümer, 1963: 3). Ramazanoğulları Beyliği'nin kurulmasıyla birlikte saha büyük ölçüde Türk yurdunun bir parçası haline gelmiş, 15. yüzyıl itibariyle de artık bölgedeki Türk hakimiyeti kökleşmiştir.

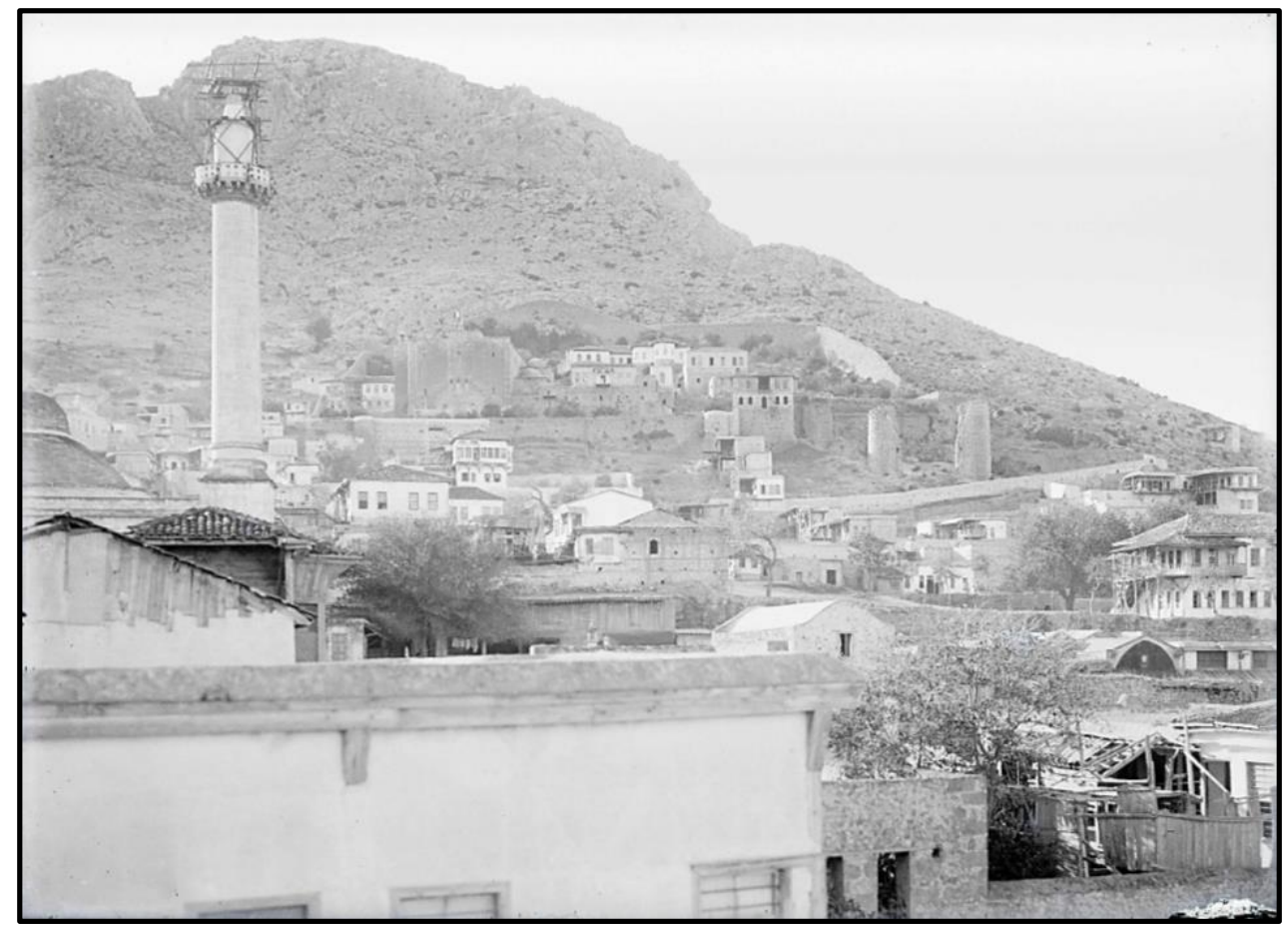

Fotoğraf 3: 1900'lerin İlk Yıllarında Kozan (Sis)'dan Bir Diğer Genel Görünüm (Archives departementales de L'Eure / Fransa)

Kozan, Osmanlı İmparatorluğu'nun son dönemlerinde ve Cumhuriyet'in ilk yıllarında çeşitli iskan hareketlerine de sahne olmuştur. İlk olarak 1800'lerin sonlarına doğru Adana, Maraş, Payas ve Sis (Bugünkü Kozan) dolaylarındaki aşiretlerin iskan edilmeleri ve kendileri için inşa olunan mahallere yerleştirilmelerine karar verilmiş, buna göre de toplam üç bin civarında hane iskan ettirilmiştir (İdikurt, 2011: 98). Sonraları özellikle Rumeli ve Girit'ten gelen Müslüman halkın bir kısmı da bu bölgede iskan ettirilmiştir (Hasgül, 2016: 86). 19. yüzyıl ortalarına gelindiğinde Kilikya olarak da nitelenen sahada Türk nüfus hakim duruma geçmiş, sahada 98.000 Türk ve Türkmen, 20 bin Kürt, 16 bin Arap, 12 bin Ermeni ve az sayıda da diğer milletlerden halklar yaşamaktaydı (Ünal ve Girginer, 2007: 63). Bununla birlikte burada belirtilmesi gereken önemli bir nokta da özellikle bazı yabancı kaynaklarda Kilikya olarak nitelendirilen saha veya özelde Adana ile yakın çevresinin geçmişe yönelik nüfus bilgileriyle ilgili yanlı, bilimsellikten uzak çok değişik yorumlar 
olduğudur. Buna göre de literatürde bölge nüfusu ve bu nüfusu oluşturan halkların sayıları çok değişkenlik göstermektedir.

\begin{tabular}{|c|c|}
\hline Tarih & Vaka \\
\hline 1869 & İdari olarak Adana Vilayeti kuruldu. \\
\hline 1893 & $\begin{array}{l}\text { Sis (Kozan) Kazası nüfusu 32.507, Kozan Sancağı nüfusu } \\
84.312 \text { 'dir. }\end{array}$ \\
\hline 1909 & $\begin{array}{l}\text { Tarihe Adana Katliamı ve Adana Olayları isimleriyle geçen } \\
\text { olaylarda bölgedeki Türkler ve Ermeniler arasında etnik } \\
\text { çatışmalar yaşanmış ve binlerce kişi yaşamını yitirmiştir. }\end{array}$ \\
\hline \multirow{2}{*}{1921} & Adana ve çevresi Fransız işgalinden kurtuldu. \\
\hline & Cebelibereket, Sancak oldu. \\
\hline 1923 & Cebelibereket Vilayeti kuruldu. \\
\hline 1926 & Kozan idari olarak vilayetken ilçe statüsüne getirildi. \\
\hline 1927 & $\begin{array}{l}\text { Cumhuriyet Dönemi ilk nüfus sayımı sonuçlarına göre } \\
\text { Kozan nüfusu } 26.685 \text { olarak tespit edildi. }\end{array}$ \\
\hline \multirow{2}{*}{1933} & Adana ilinin adı Seyhan olarak değiştirildi. \\
\hline & Cebelibereket vilayeti alınan kararla kaza oldu. \\
\hline 1936 & $\begin{array}{l}\text { Cebelibereket için yeniden il statüsüne getirilmesi talep } \\
\text { edildi. }\end{array}$ \\
\hline 1955 & Kozan'da şehir nüfusu 10.000'in üzerine çıktı. \\
\hline 1956 & Seyhan ilinin adı değiştirilerek tekrar Adana yapıldı. \\
\hline 1959 & $\begin{array}{l}\text { İmamoğlu nahiye merkezi olmuş, Kozan'ın Merkez ve } \\
\text { Sırkıntı nahiyelerinden toplam } 13 \text { köy İmamoğlu'na } \\
\text { bağlanmıştır. }\end{array}$ \\
\hline 1970 & Kozan nüfusu ilk defa 100.000 'in üzerine çıktı. \\
\hline 1986 & Adana, Büyükşehir statüsü kazandı. \\
\hline 1987 & $\begin{array}{l}\text { İmamoğlu, Kozan'dan ayrılarak müstakil bir ilçe statüsü } \\
\text { kazandı. }\end{array}$ \\
\hline 1996 & Osmaniye il statüsü kazandı ve Türkiye'nin 80 . ili oldu. \\
\hline 2011 & $\begin{array}{l}\text { Kozan'ın "İl" olması için dönemin milletvekillerinden bir } \\
\text { kısmı kanun teklifi sundu. }\end{array}$ \\
\hline
\end{tabular}

Tablo 1: Demografik ve İdari Açıdan Adana - Kozan ve Yakın Çevresinin Kronolojisi

Kozan'ın demografik yapısının izahı ve tarihsel süreçteki nüfus noktasında yaşanan değişimlerin daha iyi bir şekilde izah edilebilmesi için ilçede idari manada yaşanan değişimlerin çok iyi bilinmesi lazım (Tablo 1). Nitekim bazı dönemlerde nüfus hareketlerinden ziyade idari manada yaşanan değişimlerden kaynaklı olarak nüfusta değişimler söz 
konusu olmuştur. Kozan, Osmanlı İmparatorluğu'nun son dönemlerinde gidilen yeni yerel yönetim ve idari teşkilatlanma hareketleriyle birlikte şekillenmeye başlamıştır. 1800'lerin ilk yarısında Adana Eyaleti; Adana, Tarsus, Alanya (Alaiye), İç İl (İçel), Sis, Uzeyr ve Beylân livalarından oluşuyordu (Akbal, 1951: 623; Karpat, 2003: 52; Aydın, 2019: 10). 1864'teki Teşkilat-ı Vilayet Nizamnamesi (Vilayet Kanunu) ile birlikte daha küçük idari birimler oluşturulup merkezi yönetimin güçlendirilmesine çalışılmıştır. Başlangıçta bütünüyle Halep Sancağı'nı oluşturan bölge, daha sonra ikiye ayrılmış, 1869'da Adana Vilayeti ayrı bir ünite olarak tesis edilmiştir. Burayla birlikte aynı dönemde İçel (İç İl), Mersin, Kozan ve Cebelibereket'te ayrı birer idari yapılanmaya kavuşmuştur. Kozan Sancağı; Sis (Kozan), Kadirli, Haçin (Saimbeyli) ve Beylanköy (Feke) kazalarından oluşmaktaydı* (Şekil 1). Sancak Merkezi olan Sis ise beş mahalle, seksen köy ve Sırkıntı Nahiyesinden oluşmaktaydı (Hasgül, 2016: 30). 1900'lerin ilk yılları itibariyle Adana Vilayeti; Adana, Kozan, Cebelibereket (Cebel-i Bereket) ve Mersin sancaklarından ve toplamda 15 kazadan oluşuyordu. Kozan Sancağı da; Kozan, Haçin, Feke ve Kars-ı Zülkadriye (Kars Pazarı, Kadirli) kazalarından oluşmaktaydı (Tutar, 2002: 151; Şaşmaz, 2015: 15; Çanak ve Yeşil, 2015: 104). Fakat I. Dünya Savaşı'nı takiben tüm bu çevrenin Fransızlar tarafından işgale uğramasıyla bölgede birtakım idari değişiklikler yapılmasına gidilmiştir. Cebelibereket ise önceleri merkezi Payas iken 1877'de Yarpuz'a taşınmıştır. 1890'da Adana Vilayeti'ne bağlanan Cebelibereket'e Payas, Osmaniye, Îslahiye, Hassa ve Bulanık kazaları da bağlanmıştır (Halaçoğlu, 1993: 186). 1908'de ise Osmaniye, Sancak merkezi olmuştur. 1921'e gelindiğinde Cebelibereket sancak; 1923'te de vilayet olmuştur. 1933'te ise Cebelibereket ikiye bölünerek Adana ve Gaziantep'e paylaştırılmıştır. Daha sonraki yıllarda Adana'da yine bir takım idari değişiklikler yaşanmış ve bu durum bazı ilçe nüfuslarını etkilemiştir. 1986'da Büyükşehir olan Adana'da, ertesi yıl İmamoğlu ilçe olmuş ve Kozan'dan ayrılmıştır. 1996'ya gelindiğinde ise Osmaniye il olmuş ve Merkez ilçe, Toprakkale, Hasanbeyli, Sumbas, Kadirli, Düziçi, Bahçe ilçeleri buraya bağlanmıştır. Son duruma göre de Kozan ilçesi Osmaniye ile (Sınırının büyük bir kısmını Sumbas ilçesi oluşturmaktadır) komşu olmuştur.

\footnotetext{
* V. Cuinet, 1891 yılında yayınlanan ve yöre hakkında teferruatlı bilgiler aktardığı eserinde Kozan Sancağını; Sis, Kars, Haçin ve Feke kazalarından oluştuğunu ve toplamda 324 köyün bulunduğunu belirtmiştir.
} 


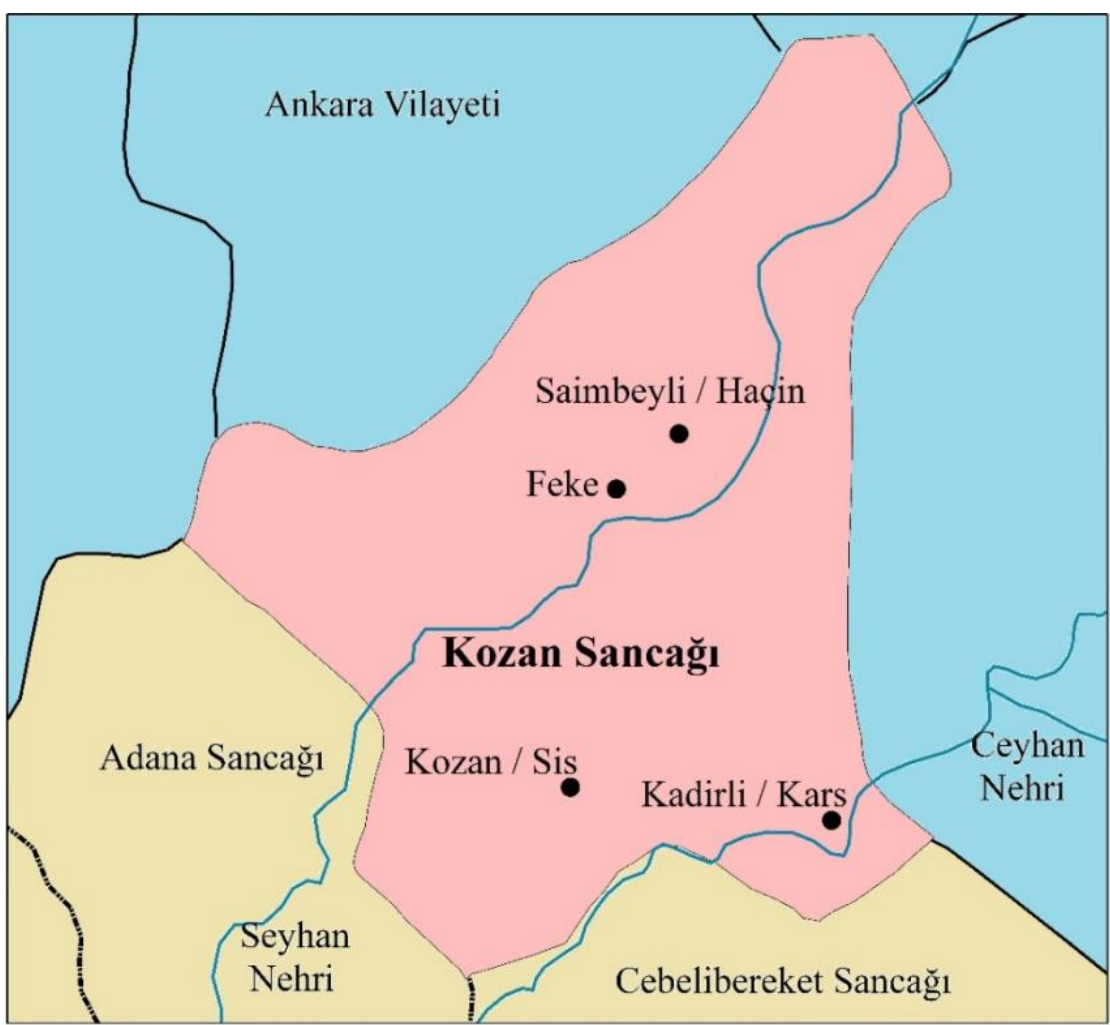

Şekil 1: Sadeleştirilmiş Kozan Sancağı'nın Lokasyonu

Kozan ile ilgili en önemli idari girişimlerden birisi de 2011'de TBMM'ye, dönemin milletvekillerinden bir kısmı tarafından Kozan'ın il olması yönünde sunulan kanun teklifidir. Söz konusu kanun teklifinde* Kozan'ın il olması ile ilgili coğrafi, iktisadi ve tarihi gerekçeler sıralanmış, nüfus konusunda da 2009 yılı ADNKS sonuçları sunulmuştur. Buna göre de Kozan'ın;

"Adana il sınırları içerisindeki en büyük iki ilçeden biri durumunda olan Kozan, birçok ilden bile daha çok nüfusa sahiptir. Toplam 87 köyü, 15 mahallesi ve 1 beldesi bulunan Kozan ilçe merkezinin, 2009 yılı adrese dayalı nüfus kayıt sistemine göre şehir merkezi nüfusu 74.521, köy ve beldelerin nüfusu 51.292 olmak üzere nüfus toplamı 125.813'e ulaşmış bulunmaktadır" (akt. Şaşmaz, 2014: 107).

ifadeleri kullanılmıştır. Buna göre Kozan iline Aladağ, İmamoğlu, Feke, Saimbeyli ve Tufanbeyli ilçelerinin bağlanması teklifi verilmiştir. Her ne kadar yakın yıllara kadar Kozan halkı ve bir kısım yöneticilerce bu görüş savunulmuş olsa da bu şekilde bir idari düzenlemeye gidilmemiştir.

\footnotetext{
* TBMM'ye sunulan dilekçe 3 Şubat 2011 tarihinde, İçişleri Bakanlığı ile Plan ve Bütçe Komisyonu'na havale edilmiştir.
} 
Kozan'ın demografik özellikleri noktasında dikkat çekilmesi gereken bir nokta da ilçedeki etnik durumdur. Daha önce de ifade edildiği üzere farklı kaynaklarda değişik rakamlar göze çarpmakla birlikte Adana geneli ve Kozan'da belli bir Ermeni nüfustan bahsedilmekteydi. İmparatorluğun son yılları için Kozan'da toplam nüfus 1900 'de 17.367 'si Müslüman, 2.262'si Gayrimüslim, toplam 19.629 kişiden; 1914 'te ise 20.763'ü Müslüman toplamda 24.830 kişiden oluşmaktaydı (Karpat, 2003: 210; Çanak ve Yeşil, 2015: 106; Aydın, 2019: 31). Gayrimüslim nüfusunun büyük bir kısmını ise Ermeniler oluşturmaktaydı. Fakat yaşanan gelişmeler sonrasında Kozan'da hiç Ermeni varlığı kalmamış ve ilçedeki 1927 yılı nüfus sayımı sonuçlarına göre 26.685 kişinin Müslüman nüfustan oluştuğu kaydedilmiştir (İstatistik Umum Müdürlüğü, 1929: 140). Yöredeki Ermeni nüfusun azalmasında özellikle tarihe 1909 Adana Olayları veya Adana Katliamı adıyla geçmiş etnik çatışmalar etkili olmuştur. Müslüman halk ve Ermeniler arasında yaşanan ve etnik bir çatışmaya dönüşen olaylarda günümüzde hala taraflar ölen kişi sayısı konusunda anlaşamamaktadırlar. Literatürde 5 bin ila 30 bin arasında Ermeni'nin öldürülmüş olduğuna dair farklı rakamların bulunduğu söz konusu olayları takiben 1915 'te yaşanan Ermeni Tehciri, bölge etnik yapısını ve nüfus miktarını büyük ölçüde değiştirmiştir*. Her ne kadar bir kısım Ermeni bölgede kalmış olsa da Ankara Antlaşmasını takiben geri kalan Ermeniler de bölgeyi kitleler halinde terk etmiştir. Sonuç olarak Kozan'da Osmanlı İmparatorluğu'nun son yılları ile Cumhuriyet Dönemi'nin başlarında oluşan bu etnik değişiklik ile ilçe günümüzdeki şeklini almıştır.

\section{CUMHURİYET DÖNEMİNDE KOZAN NÜFUSU}

Kozan, ovalık ve dağlık saha arasındaki geçiş alanında kurulmuş, güneyi ovalık, kuzeyi ise dağıktır. İlçe genel olarak çukur ova olarak bilinen geniş sahanın "Yüksek Ova" olarak adlandırılan kesiminde kurulmuştur. İlçenin ovalık kesimlerinde yükseltisi 200 metreyi bulmayan irili ufaklı kalker tepeler söz konusu olup, kuzeye doğru dağlık sahaya geçilmektedir. Kısaca Kozan için Toros Dağları ile Çukurova arasındaki hafif eğimli sahada kurulmuştur da diyebiliriz. İlçe, Deliçay ve Sümbaş (Sumbas) çayları arasında bulunmakta olup denizden ortalama yükseltisi 125 m., il merkezine uzaklığı $70 \mathrm{~km}$. olan bir yerleşmedir. İlçede yükselti güneyden kuzeye doğru artmakta,

\footnotetext{
* 1909'daki olaylarda hem Ermeniler hem de Türkler tarafından çok sayıda kayıplar verilmiş olup bu konuda hala kesin bilgiler söz konusu değildir.
} 
buna bağlı olarak güney kesimdeki ovalık alanlarda tarla tarımı ve bahçecilik yaygınlaşırken, kuzeye doğru yaylalarda hayvancılık ve ormancılık yaygınlık kazanmaktadır. Son olarak idari şeklini İmamoğlu'nun ayrılmasıyla kazanan Kozan; kuzeyde Saimbeyli ve Feke, kuzeybatıda Yahyalı (Kayseri), batıda Aladağ, güneyde İmamoğlu ve Ceyhan, doğuda da Osmaniye (Sınırın büyük bir kısmını Sumbas ilçesi oluşturmaktadır) ile komşudur (Şekil 2).

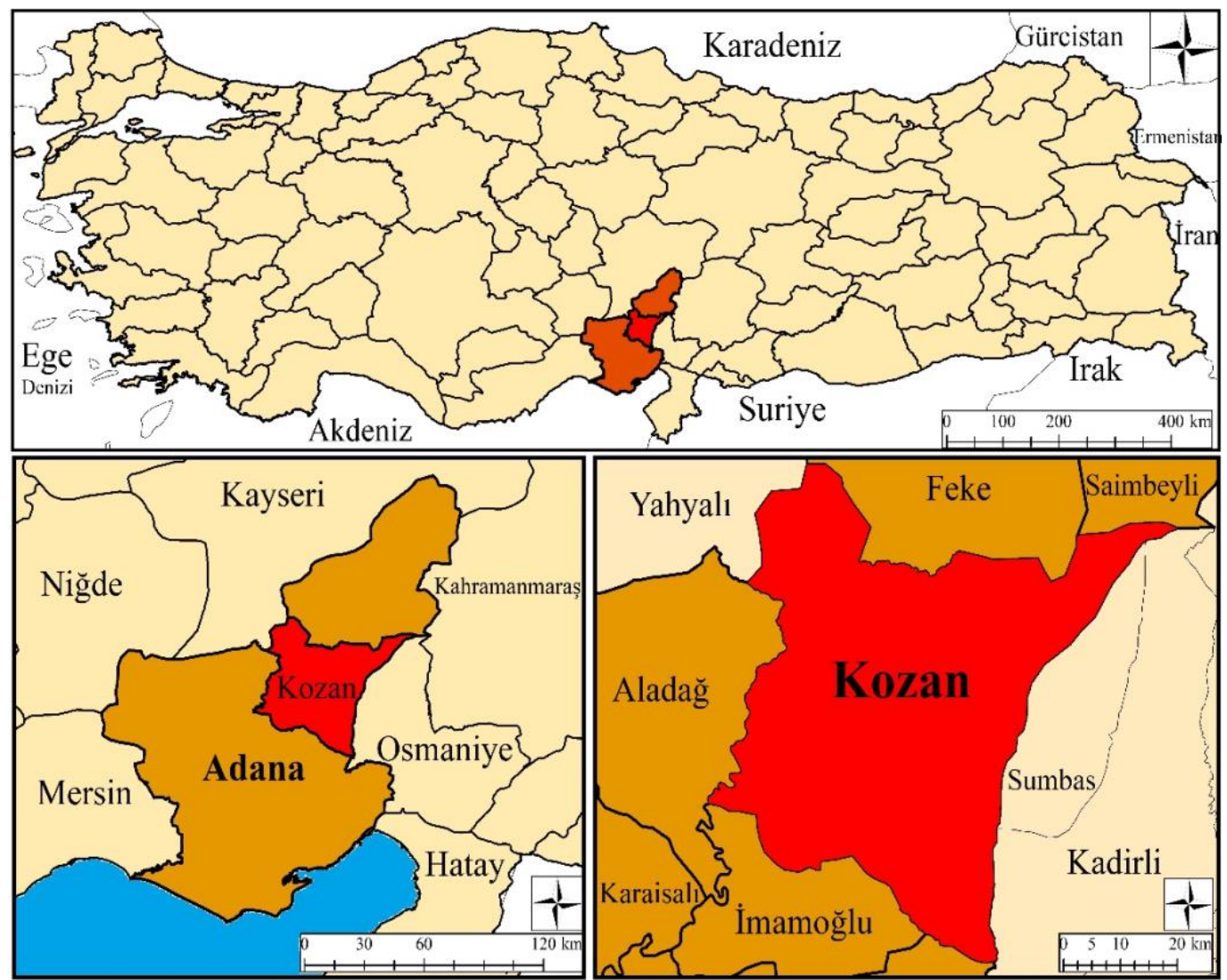

Sayfa | 115

Şekil 2: Kozan İlçesinin Lokasyonu

Kozan'da nüfusun genel özelliklerini izaha başlamadan evvel ilçe nüfusunun tarihsel süreçteki seyrini izah etmek gerekmektedir. Osmanlı İmparatorluğu'nun son döneminde her ne kadar çeşitli gayelerle (Asker durumu, vergi tespiti gibi) sayımlar yapılmış olsa da bunlar günümüzdeki nüfus sayımlarıyla kıyaslanamayacak mahiyette olup sağlıklı bilgi vermekten de uzaktır. Öte yandan özellikle İmparatorluğun parçalanıp Milli Mücadele sonrası modern Türkiye Cumhuriyeti'nin kurulması aşamasında da uluslararası kamuoyu algısı oluşturmak için çok değişik veriler de ortaya atılmıştır. Örneğin; 1831 'de Adana nüfusunun 92.619 olduğu, bunun da 81.166'sının Müslüman, 5.865'inin Kıpti, 2.826'sının Ermeni ve 2.762'sinin de Reaya olduğu belirtiliyorken Berlin Kongresi (1878)'nde Ermeni Patriği Nerses 
tarafından sunulan tebliğde ise Adana nüfusunun 134.000 civarında Hıristiyan, 86.000 kadar da Müslüman halktan oluştuğu belirtilmiştir (Akbal, 1951: 628; Karpat, 2003: 94). 1864'te yöreye giden Cevdet Paşa (1823 - 1895) tarafından yapılan incelemeler neticesinde Kozan (Sis)'da 4.308 hane, 25.848 nüfus sayılmıştır. Yine salnamelerden hareketle Kozan nüfusu 1870 'te 35.276 erkek (26.849'u Müslüman), $1877-78$ 'te 33.622, 1882'de de 21.971 (13.802'si Müslüman) olarak kayıtlara geçmiştir (Karpat, 2003: 160; Hasgül, 2016: 51). 1891 yılında basılmış olan eserinde ise Vital Cuinet (1833 - 1896), Kozan Sancağı toplam nüfusunu 60.084, sadece Sis kazasının da 9.959 kişiden (3.500 kadarı kent nüfusu) oluştuğunu belirtmiştir (Cuinet, 1891: 5). Kozan nüfusu için Cuinet tarafından verilen sayılara çoğu araştırmacı tarafından şüpheyle yaklaşılmış, söz konusu dönem için Adana Vilayet Salnamesi'nde, Kozan Sancağı için 55.156 Müslüman, 16.865 Gayrimüslim sayılmış olup toplam nüfus 72.021 olarak belirtilmiştir. Sadece Sis Kazası nüfusu ise 20.310 kişiden oluşmakta olup bunun da 18.225'i Müslüman halk teşkil etmektedir (Tutar, 2002: 162). Sonuç olarak Kozan ve çevresi için 1800 'lerin sonu ile 1900 'lerin başlarında nüfus miktarının çok değişmiş, aynı zamanda da tutarsız kayıtların olduğunu belirtmek gerekir. Kozan ve yakın çevresindeki isyanlar ve huzursuzluklar (Kozanoğulları Ailesinin faaliyetleri gibi), aşırı sıcaklık ve çevredeki bataklıklara bağlı olarak gelişen sıtma salgını, son olarak da Ermeni halkın faaliyetleri gibi faktörlerle nüfus miktarları ciddi manada değişmiştir. Osmanlı İmparatorluğu da merkezi otoriteyi kuvvetlendirmek ve bölgede yerleşik hayatı özendirmek amacıyla bir dizi uygulamaya girişmiş, asayişin sağlanması, bataklıkların kurutulması ve imar faaliyetleriyle birlikte Kırım ve Balkanlardan gelen bir kısım göçmenlerin buralarda iskan edilmesiyle yeni bir düzen sağlanmaya çalışmıştır.

\begin{tabular}{|c|c|c|c|}
\hline Yıllar & Adana Nüfusu & Kozan Nüfusu & $\begin{array}{c}\text { Kozan } \\
\text { Nüfusunun } \\
\text { Oranı (\%) }\end{array}$ \\
\hline 1927 & 227.718 & 26.685 & 11.7 \\
\hline 1935 & 383.645 & 31.151 & 8.1 \\
\hline 1940 & 375.777 & 35.752 & 9.5 \\
\hline 1945 & 418.740 & 40.563 & 9.7 \\
\hline 1950 & 508.518 & 52.844 & 10.4 \\
\hline 1955 & 628.505 & 63.940 & 10.1 \\
\hline
\end{tabular}




\begin{tabular}{|l|l|l|l|}
\hline 1960 & 760.803 & 75.883 & 9.9 \\
\hline 1965 & 902.712 & 92.885 & 10.3 \\
\hline 1970 & 1.035 .377 & 104.569 & 10.1 \\
\hline 1975 & 1.240 .475 & 115.679 & 9.3 \\
\hline 1980 & 1.485 .743 & 130.800 & 8.8 \\
\hline 1985 & 1.725 .940 & 143.373 & 8.3 \\
\hline 1990 & 1.934 .907 & 117.704 & 6.1 \\
\hline 2000 & 1.849 .478 & 130.875 & 7.0 \\
\hline 2007 & 2.006 .650 & 123.980 & 6.2 \\
\hline 2010 & 2.085 .225 & 127.100 & 6.1 \\
\hline 2012 & 2.125 .635 & 127.926 & 6.0 \\
\hline 2015 & 2.183 .167 & 129.242 & 5.9 \\
\hline 2019 & 2.237 .940 & 131.633 & 5.9 \\
\hline
\end{tabular}

Tablo 2: Cumhuriyet Dönemi Nüfus Sayımlarına Göre Adana ve Kozan Nüfusları ve Kozan Nüfusunun Oransal Değerleri (TÜİK, 2020)

Araştırma sahamız bugün Adana'ya bağlı olmakla beraber bölge, idari manada çok değişikliklerin yaşandığı bir yer olmuştur. 1927'de Adana ve Cebelibereket ayrı birer il iken sonrasında Cebelibereket ilçe olmuş, 1933 - 1956 yılları arasında da Adana ilinin adı değiştirilerek Seyhan olarak anılmaya başlanmıştır. 1927'deki idari yapılanmaya göre Adana nüfusu 227.718, Kozan nüfusu 26.685, Cebelibereket nüfusu da 108.091 kişiden oluşuyordu (İstatistik Umum Müdürlüğü, 1929). Söz konusu dönemde Adana, 6 ilçeden oluşan bir idari yapıya sahip olup bunlar Merkez ilçe ile birlikte Saimbeyli, Feke, Karaisalı, Kozan ve Kars-ı Zülkadriye (Kadirli) ilçeleriydi. Kozan, Adana'nın Cumhuriyet ile birlikte temelleri ilk atılan ilçe belediyelerinden birisidir. 1987 'de İmamoğlu'nun müstakil bir ilçe olarak kuruluşu ile bugünkü sınırlarını alan Kozan'ın 1997'deki Köy Envanter Etüdü'ne göre toplam 86 köyü bulunmakta, bunların da 64 tanesini orman içi veya orman kenarı köyler oluşturmaktaydı (DİE, 2002: 4). İlçe, günümüzde 15'i ilçe merkezinde bulunan toplam 103 mahalleden oluşan bir idari yapılanmaya sahiptir. Söz konusu mahallelerin $15^{\prime}$ i merkeze bağlı olup geri kalanlar kırsalda yer almaktadır. 


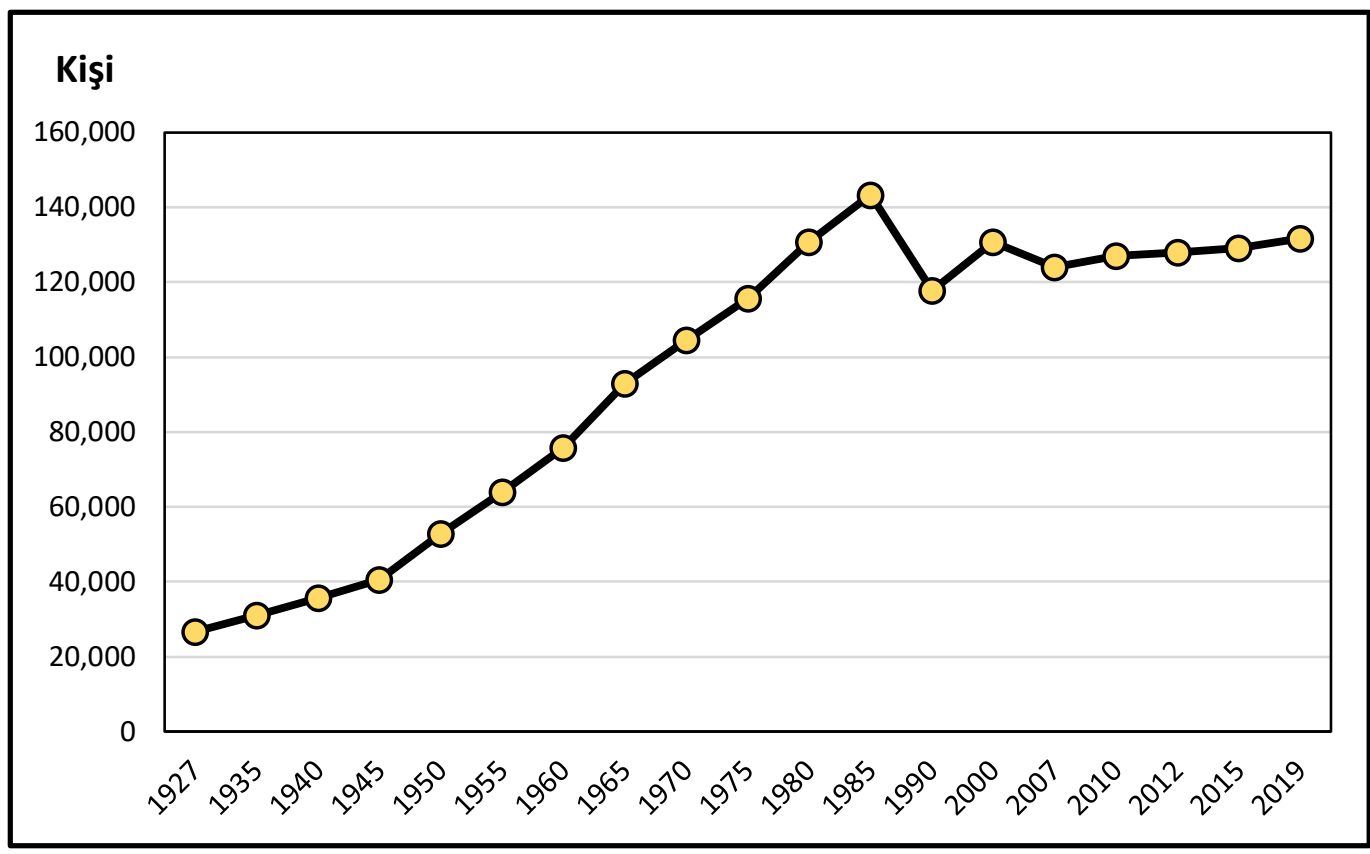

Şekil 3: Kozan İlçesi Toplam Nüfusunun Yıllar İtibariyle Değişimi (TÜİK, 2020)

Kozan ilçesindeki nüfusun gelişimi ve Adana il genelindeki payına baktığımızda ilçe, 1927'den 1975'e değin il genelinde ortalama \%10 $(\% 9,91)$ 'luk bir nüfus kitlesini barındırmıştır. Fakat bu oran Adana'nın, özellikle de sahil ilçelerin yoğun göç alması başta olmak üzere eğitime bağlı nüfus hareketleriyle yaşanan nüfus artışı neticesinde Kozan aleyhinde bir durum yaratarak ilçenin oransal payı yıldan yıla daralmış, İmamoğlu'nun ayrılmasıyla da payı daha da küçülmüştür. Cumhuriyet tarihinin ilk sayımının gerçekleştiği 1927 sonuçlarına göre Adana toplam nüfusunun \%11,7'lik payını teşkil eden Kozan'da 26.685 kişi sayılmış, söz konusu nüfusun önemli bir kısmı da kırsal kesimde (21.615 kişi) yaşamaktaydı. Zaman içerisinde Kozan nüfusu kayda değer artışlar göstermiştir. Örneğin; 1945'ten 1950'ye \%30,3 oranında; 1960 'tan 1965 'e \%22,4 oranında artış kaydedilmiştir. Fakat yakın yıllara doğru nüfus artış oranlarında da düşüşler yaşanmış olup 2010'dan 2019'a değin geçen sürede nüfus artış oranı \%3,5 ile sınırlı kalmıştır. İlçede 1985 'te 143.373 olan nüfus, 1986'da İmamoğlu ilçesinin kurulmasıyla birlikte Kozan nüfusunda 1990'a gelindiğinde ciddi bir düşüş yaratmış ve ilçe nüfusu 117.704 olmuştur (Tablo 2 Şekil 3). 2000 yılına gelindiğinde ilçe nüfusu, 1980'deki nüfusu yakalamışsa da ADNKS'ye geçişle birlikte elde edilen daha sağlıklı veriler neticesinde ilçe nüfusu 2007 'de 123.980 olarak tespit edilmiştir. Son olarak 2019'a gelindiğinde ilçe nüfusu tekrar 130 bini aşmış 
(131.633 kişi) görünse de nüfus artış hızı önceki yıllara kıyasla çok düşüktür.

Kozan'daki nüfusun artış ve azalmasında her yerde olduğu gibi idari kararlar, göçler, doğum ve ölümler temel belirleyicilerdir. Kozan nüfusunda ise son yıllardaki nüfus miktarında yaşanan değişimlerde doğum ve ölüm sayıları en önemli belirleyiciler olmuştur. İlçedeki son 6 yılda kaydedilen doğum sayılarına baktığımızda ölüm sayısındakinin aksine dikkat çekici gerilemeler yaşanmıştır. Kozan'da 2014'te kaydedilen toplamda 2.076 doğum, 2019'a gelindiğinde \%24,6 oranında gerileyerek 1.565 'e inmiştir (Tablo 3). Düzenli bir şekilde gerileyen doğum sayısında da tıpkı ölüm sayısında olduğu gibi erkek sayısı kadın sayısından fazla olmuştur. Kozan'ın nüfus artış durumu yanı sıra nüfusun azalmasındaki faktörlerden biri olan ölüm değerlerine baktığımızda; ilçede esasında önemli bir gelişmişlik göstergesi olarak ölüm oranı büyük ölçüde azalmış ve ortalama yaşam süresi uzamıştır. Kozan'ın 2009 - 2019 yılları arasındaki ölüm değerlerinde yıldan yıla önemli bir artış olmadığı anlaşılmaktadır (Tablo 3). İlçede 2009'da toplamda 651 kişi ölmüş, ertesi yıl sadece \%1,6'lık artışla 662 olmuş, 2019'da ise \%28,5'lik artışla 837 olmuştur. Kozan'da 2009 - 2019 yılları arasında her yıl ölen erkek sayısı kadınlardan daha fazla olmuştur. Bu durum ilerleyen bölümde izah edilmiş olan nüfusun medeni durumunda da kendini net bir şekilde belli etmektedir. Sadece doğum ve ölüm sayıları göz önüne alındığında 2018'den 2019'a ilçe nüfusu 1.138 kişi artmış, nüfusa doğumla 1.565 kişi katılmış, ölümle de 837 kişi azalmıştır. Söz konusu toplam artışta sınırlı da olsa dışarıdan aldığı göç (Ekseriyetle atamalarla gerçekleşen nüfus hareketi, evlilik yoluyla yapılan yer değişikliği veya eğitime bağlı hareketlilik) etkili olmuştur.

\begin{tabular}{|c|c|c|c|c|c|c|}
\hline \multirow{2}{*}{ Yıllar } & \multicolumn{3}{|c|}{ Doğum Sayısı } & \multicolumn{3}{c|}{ Ölen Kişi Sayısı } \\
\cline { 2 - 7 } & Erkek & Kadın & Toplam & Erkek & Kadın & Toplam \\
\hline 2009 & - & - & - & 380 & 271 & 651 \\
\hline 2010 & - & - & - & 385 & 277 & 662 \\
\hline 2011 & - & - & - & 367 & 293 & 660 \\
\hline 2012 & - & - & - & 444 & 305 & 749 \\
\hline 2013 & - & - & - & 379 & 288 & 667 \\
\hline 2014 & 1.028 & 1.048 & 2.076 & 386 & 310 & 696 \\
\hline 2015 & 1.004 & 937 & 1.941 & 412 & 352 & 764 \\
\hline
\end{tabular}




\begin{tabular}{|l|l|l|l|l|l|l|}
\hline 2016 & 985 & 892 & 1.877 & 441 & 386 & 827 \\
\hline 2017 & 926 & 859 & 1.785 & 439 & 345 & 784 \\
\hline 2018 & 891 & 835 & 1.726 & 439 & 353 & 792 \\
\hline 2019 & 823 & 742 & 1.565 & 482 & 355 & 837 \\
\hline
\end{tabular}

Tablo 3: Kozan İlçesinde Seçilmiş Yıllara Göre Doğan ve Ölen Kişi Sayıları (TÜİK, 2020)

Kozan nüfusunun büyüklüğünün daha iyi anlaşılabilmesi için hazırlanan şekil 4 incelendiğinde, ilçenin genel olarak il bazında ilk 5 'te yer aldığı anlaşılmaktadır. Esasında geçmişe yönelik izahta ve genel olarak Adana'da çok sık yaşanmış olan idari değişiklikler nüfus ile ilgili yorumları güçleştirse de Kozan özelinde yapılacak değerlendirmede Adana'nın nüfus açısından belli başlı ilçeleri arasında yer aldığı söylenebilir. Örneğin; 1927 sayım sonuçlarına göre Kozan 26.686 kişilik nüfusuyla Adana'da 3. sırada yer almaktaydı. Öte yandan Adana'nın diğer ilçelerinin almış olduğu yoğun göç ve doğum hızı gibi faktörler dikkate alındığında her ne kadar Kozan nüfusu da artış eğiliminde olsa da Adana genelindeki oransal değeri zaman içerisinde önemli ölçüde daralmıştır. Şekil 4'teki 1940 verilerine göre Kozan toplam 35.752 kişilik nüfusuyla Adana'da \%9,5'lik bir paya sahip olmuştur. 1970'e gelindiğinde ilçenin nüfusu 104.569 olmuş, payı da $\% 10,1$ 'e yükselmiştir. Aynı yıl Tufanbeyli, Feke, Yumurtalık, Saimbeyli ve Pozantı nüfus toplamları (87.825 kişi) Kozan nüfusuna yetişememiştir. 1990'a gelindiğinde idari olarak 17 ilçeden oluşan Adana'da, Kozan 117.704 kişilik nüfusuyla 5. sırada yer almış fakat oransal açıdan payı \%6,1'e gerilemiştir. Söz konusu dönemde Kozan hem nüfus miktarı hem de oransal açıdan Kadirli ile birbirlerine çok yaklaşmışlardır. Son olarak 2019'daki duruma baktığımızda Kozan nüfusu 131.633'e çıkmışsa da oransal değeri \%5,9'a kadar gerilemiştir (Şekil 4). Bu dönemde ilçe nüfusu 100 binin üzerinde olan ilçeler arasında son sırada yer almıştır. Buna karşılık aynı yıl Karaisalı, Pozantı, Yumurtalık, Tufanbeyli, Feke, Aladağ ve Saimbeyli toplam nüfusları (124.854 kişi) Kozan nüfusuna yetişememiştir. Sonuç olarak da Adana il genelinde nüfusun oldukça dengesiz bir dağılım gösterdiği söylenebilir. Yüzölçümü olarak Adana'nın en geniş ilçesi olan Kozan'da 
nüfus her ne kadar artıyor olsa da Seyhan, Yüreğir ve Çukurova'ya kıyasla nüfus yoğunluğunun çok daha düşük olduğu anlaşılmaktadır.

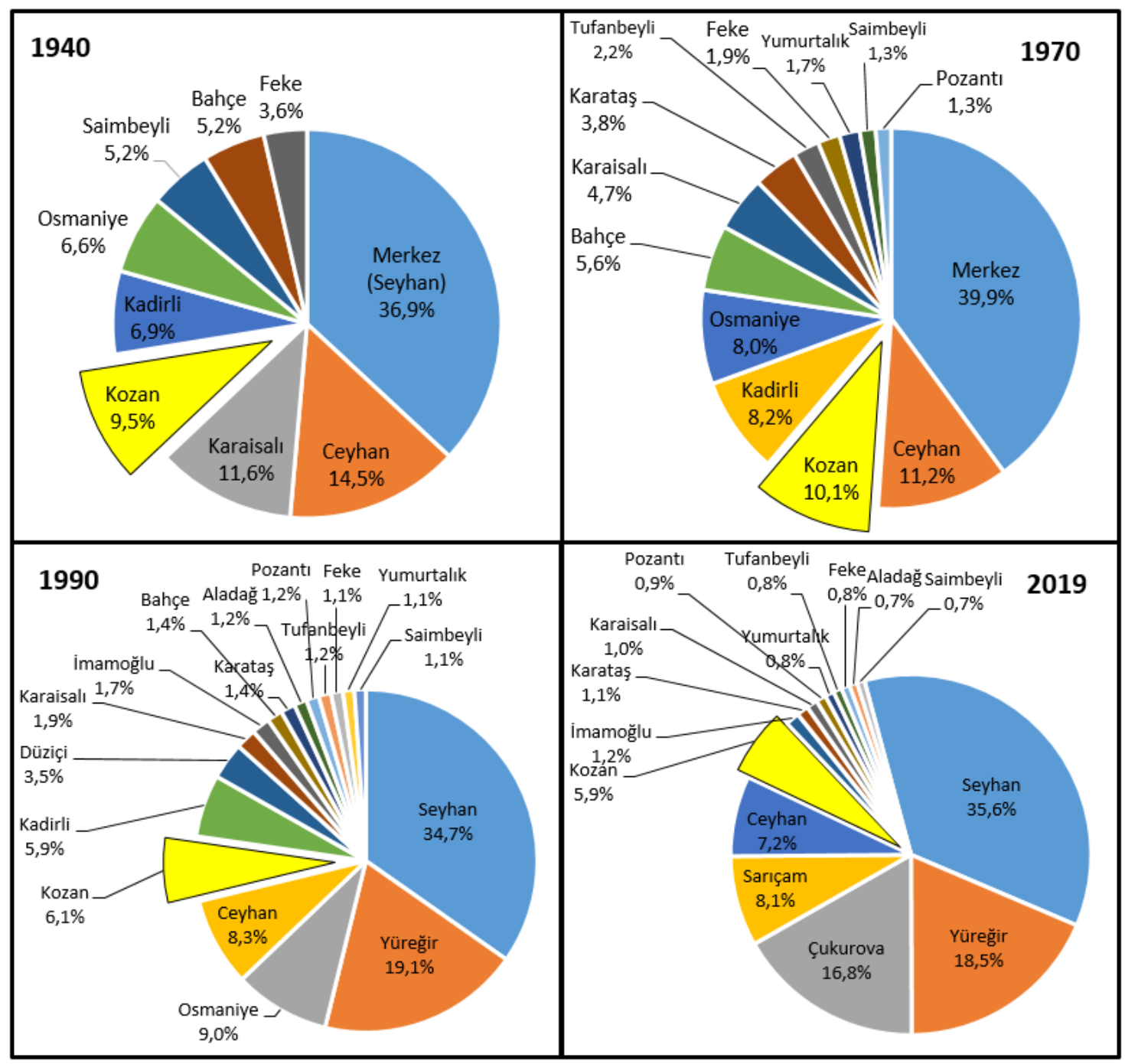

Sayfa | 121

Şekil 4: Seçilmiş Yıllar İtibariyle Adana'da İlçeler Ölçeğinde Nüfusun Oransal Dağılımı (TÜİK, 2020)

Kısaca Kozan ilçesi dahilinde nüfusun dağılımına baktığımızda ilçede Kozan şehri ve çevresinde nüfusun yoğunlaşmaktadır. 2019 verilerine göre nüfusu 10.000'in üzerinde olan 3 mahalle (Karacaoğlan, Tufanpaşa, Türkeli) ilçe toplam nüfusunun \%27,5'ini barındırmaktadır. İlçede 23 mahallenin nüfusu da 1.000 ila 10.000 arasında değişiklik göstermektedir. Nüfusu kalabalık mahallelerin tamamı ilçenin kabaca güney yarısında bulunmaktadır. Kozan şehri ve yakın çevresi ile buranın hem doğusu hem de batısı yoğun nüfuslu mahalleleri oluşturmaktadır. Kuzeye doğru ise nüfus seyrekleşmeye başlamaktadır. Nitekim ilçede nüfusu 400 kişinin altındaki 50 mahallenin ve 200 kişinin altındaki 19 mahallenin büyük bir kısmı 
kuzeye doğru ilçenin yüksek (Yayla olarak da adlandırılan) kesimlerinde bulunmaktadır.

\section{KOZAN'DA ŞEHİR VE KIR NÜFUSU}

Bir sahadaki şehir ve kır nüfusu, oranın iktisadi ve sosyal açıdan gelişmişlik düzeyi açısından önemli belirleyiciler olmuştur. Yakın yıllara kadar kırsal nüfusun fazla ve de yoğun olduğu yerleşmeler; geri kalmış, nüfusu oluşturan bireylerin vasıfları düşük, demografik anlamda geri kalınmış yerler olarak değerlendirilmekteydi. Hâlbuki özellikle son yıllarda başta zirai hayatta yaşanan gelişmelerle bu değerlendirmeden gelişmiş ülkeler ivedilikle uzaklaşmaktadırlar. Şehirlerin kapasitelerinin üzerinde nüfuslanmasıyla, kırsal kesimdekilerden çok daha düşük vasıflı bir nüfus kitlesi ortaya çıkmış, şehrin yerli halkı tarafından banliyölere itilmiş kitleyle sosyal, iktisadi, ekolojik çok sayıda sorunlar dizisi ortaya çıkmıştır. Buna göre de bir ülkede şehirli nüfusun çok, kırsal nüfusun az olması ve de bunun bir gelişmişlik göstergesi olması fikri eskisinden daha da tartışılır bir hal almıştır.

Türkiye'de de hala yaygın bir şekilde gelişmişlik göstergesi olarak; toplam nüfusun büyük bir kısmının şehirli, sınırlı bir kitlenin de kırsal nüfusunu oluşturan ülke algısı oldukça yaygındır. Özellikle de tartışmalı "Büyükşehir" statüsü ve bunun gerekleri de kırsal nüfus kavramını daha da tartışmalı bir noktaya getirmiştir. 12.11.2012 tarihinde kabul edilen 6360 sayılı Kanunla Türkiye'deki Büyükşehir Belediyeli illerin sayısı 16'dan 30'a yükseltilmiştir. Bu yasayla, bu illerdeki üst düzey yerel yönetim organı olan İl Özel İdareleri'nin tüzel kişiliklerine son verilerek, görevleri tümüyle Büyükşehir Belediyelerine devredilmiştir. Ayrıca, köy muhtarlıkları ile belde belediyeleri kaldırılarak, bu organların bulunduğu yerleşmeler mahalle statüsüne dönüştürülmüştür (Sertkaya Doğan ve Şahin, 2020). Buna bağlı olarak da "Büyükşehir" statüsündeki illerin kırsal nüfusları 0 (sıfır) kabul edilmektedir. Sonuç olarak da hem Türkiye'nin toplam kırsal kesim nüfusu hem de araştırma sahamız gibi yerlerde gerçek manada kırsal kesim olarak değerlendirilebileceğimiz sahadaki kitleyle ilgili belirsiz bir durum ortaya çıkmıştır.

2012'deki düzenlemeyle birlikte Adana ve Kozan'ın şehir ve kır nüfusundaki değişimi 1927 sayımlarından başlayarak inceleyecek olursak Adana'da şehir nüfusu düzenli ve zaman zaman hızlı bir şekilde artarken kırsal nüfusu ise 1980 'e değin düzenli bir şekilde artmışsa da sonrasında azalma eğilimine girmiştir. 2012'ye gelindiğinde de son 
kırsal kesim resmi rakamlarına göre Adana'da 239.011 kişi kırsal nüfusunu oluşturmuştur (Tablo 4). 2012'den sonra ise ilgili düzenlemeye bağlı olarak il toplam nüfusu şehir nüfusu olarak kabul edilmektedir. Kozan'daki duruma baktığımızda ise Adana'dakinden daha farklı bir durum göze çarpmaktadır. Kozan'da şehir nüfusu 1927 'de 5.266 olup 1950'ye değin kayda değer bir artış göstermemiştir. Örneğin ilçedeki şehir nüfusundaki değişim 1927'den 1940'a kadar 13 yıllık süreçte \%7'lik bir değişim göstermiştir. 1950 'lerden sonra ise şehir nüfusu çok daha hızlı bir artış sürecine girmiştir. Yine bu durumu da örneklendirecek olursak 1950'deki 7.867 kişilik şehir nüfusu 10 yıl sonra \%92,6 oranında artış göstererek 15.159 olmuştur. Kozan'da 1985 'e gelindiğinde şehir nüfusu 50 bini aşmış, 2000 'de 75.833, 2012'de de 79.943 olmuştur (Tablo 4). 2012'den sonraki şehir nüfusundaki dikkat çekici artış Kozan'daki tüm nüfusun şehir nüfusu kabul edilmesinden ileri gelmektedir. Buna göre de 2019 itibariyle ilçenin şehir nüfusu 131.633 olmuştur. Kozan'ın kırsal kesim nüfusunun değişimi ise hem Adana genelinden farklı bir yapı sergilemekte hem de düzensiz bir değişim sergilemektedir. Kozan'daki farklııı, ilçenin yoğun bitkisel üretim, hayvancılık ve ormancılık yapılan bir saha olmasına bağlı hakim iktisadi faaliyeti ziraatın oluşturmasından kaynaklı olarak kırsal kesim nüfusunun fazlalığı ve 1927'den 1985'e değin sürekli ve hızlı bir şekilde artmasıdır. Ayrıca ilçede 1927'den 1990'a kadar da kırsal kesim nüfusu şehir nüfusundan oldukça fazla olmuştur (Tablo 4). Örneğin 1970'te ilçe toplam nüfusunun \%75'ini kırsal nüfus oluşturmaktaydı. Fakat 1985 'ten itibaren ilçe kırsal nüfusunda dikkat çekici gerilemeler kaydedilmiştir. İlçenin 1985'teki 93.049 kişilik kırsal kesim nüfusu \%40,8'lik azalmayla 2000'de 55.042 'ye gerilemiştir. Son olarak 2012 'de ise 47.983 kişilik kırsal kesim nüfusu sonraki yıllarda 0 (sıfır) kabul edilmiştir. Söz konusu yılda kırsal kesim nüfusunun 24.164'ü erkek, 23.819'u da kadındır (TÜİK, 2020).

\begin{tabular}{|c|c|c|c|c|}
\hline \multirow{2}{*}{ Yıllar } & \multicolumn{2}{|c|}{ Adana } & \multicolumn{2}{c|}{ Kozan } \\
\cline { 2 - 5 } & Şehir Nüfusu & Kır Nüfusu & Şehir Nüfusu & Kır Nüfusu \\
\hline 1927 & 82.026 & 145.709 & 5.266 & 21.615 \\
\hline 1935 & 109.839 & 273.806 & 5.040 & 26.111 \\
\hline 1940 & 118.506 & 257.271 & 5.672 & 30.080 \\
\hline 1945 & 139.493 & 279.247 & 6.821 & 33.742 \\
\hline 1950 & 166.800 & 342.800 & 7.867 & 44.977 \\
\hline 1955 & 238.327 & 390.178 & 11.356 & 52.584 \\
\hline
\end{tabular}




\begin{tabular}{|c|c|c|c|c|}
\hline 1960 & 334.039 & 426.764 & 15.159 & 60.724 \\
\hline 1965 & 422.298 & 480.414 & 20.236 & 72.649 \\
\hline 1970 & 525.668 & 509.709 & 26.097 & 78.472 \\
\hline 1975 & 706.186 & 534.289 & 32.045 & 83.634 \\
\hline 1980 & 842.845 & 642.898 & 42.462 & 88.338 \\
\hline 1985 & 1.142 .201 & 583.739 & 50.324 & 93.049 \\
\hline 1990 & 1.350 .339 & 584.568 & 54.451 & 63.253 \\
\hline 2000 & 1.397 .853 & 451.625 & 75.833 & 55.042 \\
\hline 2007 & 1.611 .262 & 395.388 & 72.463 & 51.517 \\
\hline 2010 & 1.836 .432 & 248.793 & 76.864 & 50.236 \\
\hline 2012 & 1.886 .624 & 239.011 & 79.943 & 47.983 \\
\hline 2015 & 2.183 .167 & - & 129.242 & - \\
\hline 2019 & 2.237 .940 & - & 131.633 & - \\
\hline
\end{tabular}
2020)

Tablo 4: Yıllar İtibariyle Adana İli ve Kozan İlçesinin Şehir ve Kır Nüfusları (TÜİK,

Kozan'daki şehir ve kır nüfusunun değişiminin ardından söz konusu nüfus kitlelerinin oransal değerlerine baktığımızda ilk olarak şehir nüfusu özelinde ilçedeki şehir nüfusunun Adana genelinde çok küçük bir dilimi oluşturduğu gözlenmektedir. Örneğin; 1945 genel nüfus sayımına göre Adana genelindeki şehirli nüfusun (139.493 kişi) sadece \%4,8'i Kozan'da yaşamaktaydı. 1975'e gelindiğinde ise bu oran biraz daha daralarak \%4,5 olmuştur. Her ne kadar Kozan'da şehir nüfusu artış gösteriyor olsa da bu durum oransal olarak kendini gösterememiştir. Daha yakın yıllardaki duruma baktığımızda ise 1980'de 42.462 kişilik şehir nüfusuyla Kozan'ın payı önceki yıllardan farklı olarak \%5 olmuşsa da 2012'ye gelindiğinde yeniden daralarak \%4,2 olmuştur (Şekil 5). 2012'deki Büyükşehir statüsüyle birlikte gerek Adana'nın gerekse de Kozan'ın tüm nüfusunun şehir nüfusu kabul edilmesiyle birlikte her ne kadar oransal açıdan artış olsa da bu durum sadece mevzuat değişikliğinden kaynaklanmaktadır. Nitekim 2019'da Kozan şehir nüfusunun Adana içerisindeki payı \%5,9 olmuş olsa da hala düşük bir oran olarak dikkat çekmektedir. 


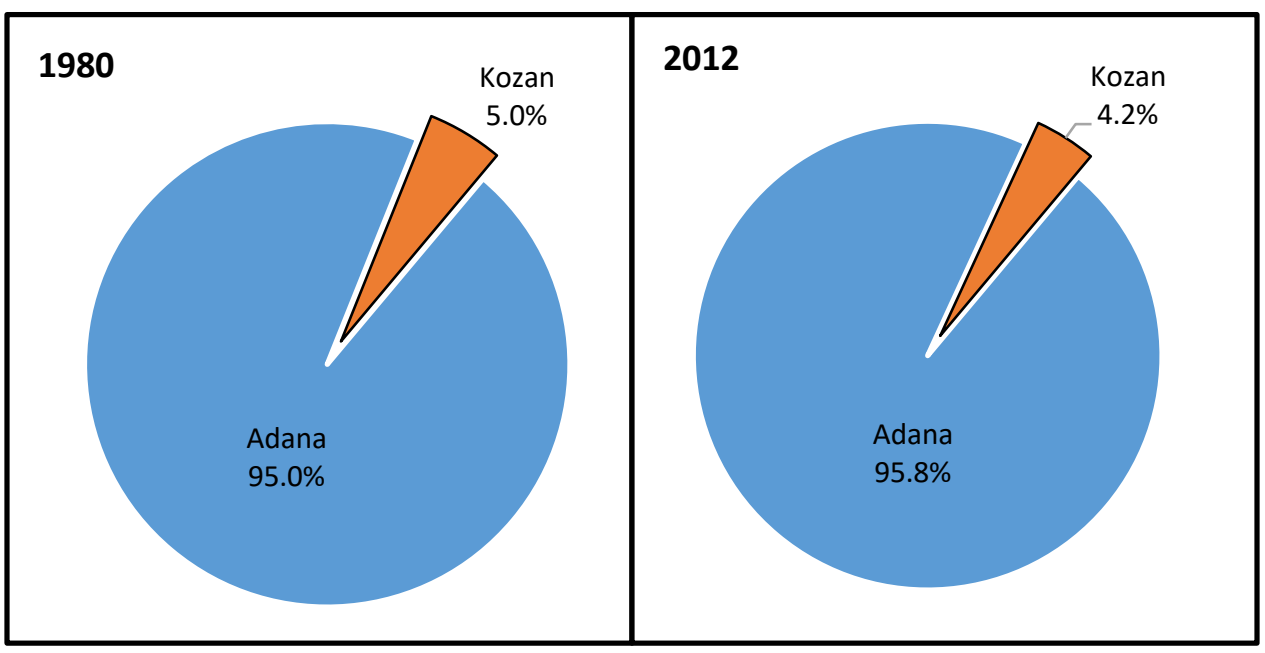

Şekil 5: 1980 ve 2012 Yıllarında Adana ve Kozan'ın Şehir Nüfusları Oranları (DİE, 1980; TÜİK, 2020)

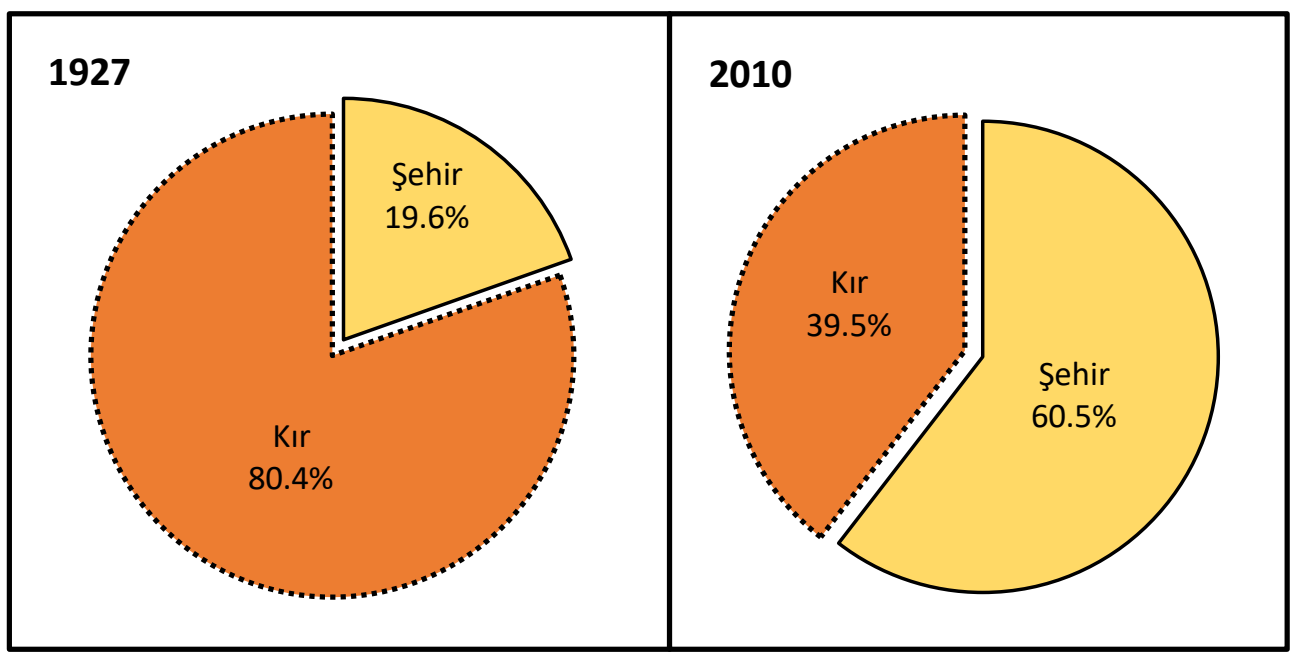

Sayfa | 125

Şekil 6: 1927 - 2010 Yıllarında Kozan İlçesinin Şehir ve Kır Nüfuslarının Oransal Değerleri (İstatistik Umum Müdürlüğü, 1929; TÜİK, 2020)

Türkiye geneli göz önüne alındığında nüfus politikaları ve diğer bir takım idari uygulamalarla şehir nüfusunun artışı ve kırsal nüfusun gerilemesi genel yargısı araştırma sahamız için de söz konusudur. Kozan'ın şehir ve kır nüfuslarının oransal olarak değişimlerine baktığımızda da bu durum tablo 4 ve şekil 6'da açıkça görülebilmektedir. İlgili şekilde 1927 'deki oransal dağılıma bakıldığında şehir nüfusunun \%20'yi dahi bulmadığı görülmekte olup kırsal kesim nüfusunun $\% 80,4$ olması Kozan sosyo-ekonomik hayatı için net bir fikir verebilmektedir. 2010'a gelindiğinde ise şehir nüfusu \%60'ı aşmış, başka bir ifadeyle Kozan nüfusunun yarıdan fazlası şehirli nüfustan oluşur hale gelmiştir. Kırsal kesim nüfusu aynı yıl \%39,5'e gerilemiş, 
son olarak kır nüfusunun sayıldığı 2012'de ise oran \%37,5 ile tarihinin en düşük payına ulaşmıştır.

Kozan İlçesinde Nüfus Yoğunlukları: İnceleme sahasındaki nüfus yoğunluklarına baktığımızda ilk olarak aritmetik nüfus yoğunluğu, yani km²'ye düşen kişi sayısı bakımından Adana geneli ve Kozan ölçeğinde zaman içerisinde nüfus artışından kaynaklı olarak değişimler yaşanmıştır. Cumhuriyet döneminin ilk nüfus sayımı sonuçlarına göre Adana'da km²'ye sadece 18 kişi düşüyorken günümüzde bu değer 161 olmuştur. Kozan özelinde baktığımızda da 1927'deki aritmetik nüfus yoğunluğu ilçede 11 kişiyken, 1955'te 31, 1970'te 49, 1990'da 66 ve 2019'a gelindiğinde de sayı 69'a yükselmiştir. Fakat burada belirtilmesi gereken önemli bir nokta da Adana gibi idari değişikliklerin çokça yaşandığı bir yer için en sağlıklı yoğunluk değerlerinin son yıllara ait değerler olduğudur. Kozan'a komşu ilçelerdeki yoğunluk ise birbirinden çok farklı olup nüfus bakımından Adana'nın 5. büyük ilçesi olan Ceyhan'da km²'ye 112 kişi düşmekte ve diğer hiçbir komşu ilçede bu değere yaklaşılmamıştır (Tablo 5). Kozan'daki değere en yakın olan İmamoğlu'nda 62 olan değer, Aladağ, Feke ve Saimbeyli'de 20 kişiyi dahi bulmamıştır.

\begin{tabular}{|c|c|c|c|c|}
\hline $\begin{array}{l}\text { İl ve } \\
\text { İlçeler }\end{array}$ & $\begin{array}{c}\text { Yüzölçümüü } \\
\left(\mathbf{k m}^{2}\right)^{*}\end{array}$ & $\begin{array}{l}\text { Tarım } \\
\text { Alanı } \\
\text { (ha.) }\end{array}$ & $\begin{array}{l}\text { Aritmetik } \\
\text { Nüfus } \\
\text { Yoğunluğu } \\
(\text { kişi//km²) }\end{array}$ & $\begin{array}{c}\text { Fizyolojik } \\
\text { Yoğunluk } \\
\left(\mathbf{k i s ̧ s i / k m ²}^{2}\right)\end{array}$ \\
\hline Adana & 13.844 & 476.725 & 161 & 469 \\
\hline Kozan & 1.903 & 57.209 & 69 & 230 \\
\hline Ceyhan & 1.426 & 84.995 & 112 & 189 \\
\hline Aladağ & 1.340 & 7.326 & 12 & 220 \\
\hline Feke & 1.218 & 6.809 & 13 & 248 \\
\hline Saimbeyli & 989 & 11.829 & 14 & 125 \\
\hline İmamoğlu & 445 & 31.841 & 62 & 87 \\
\hline
\end{tabular}

Tablo 5: Adana - Kozan ve Komşu İlçelerin 2019 İtibariyle Nüfus Yoğunlukları

(Yüzölçümleri: Harita Genel Müdürlüğü, 2014; Tarım Alanları: TÜİK, 2020)

Fizyolojik nüfus yoğunluğu açısından baktığımızda ise artan nüfus, tarım alanlarının amaç dışı kullanımı ve türlü sebeplerle yitirilmesi (Erozyon gibi) neticesinde Adana genelinde fizyolojik yoğunluk ciddi ölçüde artış göstermektedir. 2019 itibariyle il genelinde

\footnotetext{
* Yüzölçümlerine su alanlarının dahil edilip edilmemesine göre kaynaklarda farklılık gösterebilmekte olup Kozan için 1.873 km²’lik yüzölçümü de yaygın bir şekilde kullanılmaktadır.
} 
ekilebilir alanlar özelinde $\mathrm{km}^{2}$ 'ye 469 kişi isabet etmiştir (Tablo 5). Kozan'daki duruma baktığımızda ise kabaca Adana genelinin yarısı kadar bir yoğunluk olduğu anlaşılmaktadır ve aynı yıl söz konusu alanlara denk gelen kişi sayısı 230 olarak hesaplanmıştır. Ekilebilir alan bakımından Aladağ ve Feke'nin birkaç katı kadar tarım alanına sahip olan Kozan'ın söz konusu yoğunluk cinsinden bu iki ilçeyle yakın değerlere sahip olması nüfus - arazi dengesinin birbirine yakın olmasıyla alakalıdır. Komşu ilçeler içerisinde Saimbeyli (125 kişi/km²)

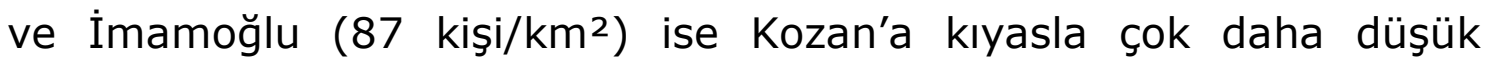
yoğunluklara sahiptir.

\section{KOZAN NÜFUSUNUN YAPISAL ÖZELLİKLERİ}

Nüfusun yapısı, nüfusun yaşadığı sahanın iktisadi özellikleri konusunda, daha genel bir ifadeyle sınırları belli bir yerdeki sosyoekonomik durumun tespitinde, nüfusun kültür düzeyinde önemli veriler sağlamaktadır. Nüfusun yapısal özellikleri aynı zamanda o sahada kısa - orta ve de uzun vadede alınması gereken tedbirler ve yapılacak yatırımlar açısından da çok önemli veriler sağlamaktadır. Bu açıdan Kozan'daki nüfus yapısını detaylandırdığımızda;

a. Nüfusun Yaş Yapısı: Bir ülke, bölge, şehir veya sınırları belli herhangi bir bölgenin nüfus yapısı ve buna bağlı olarak da o sahanın gelişmişlik düzeyi ile ilgili nüfus piramitleri önemli göstergelerdir. Kozan'ın nüfus piramidi ve ilçede nüfus bilgisinden hareketle yapılabilecek çıkarımlara baktığımızda ilk etapta 1985'teki durum ele alınmış ve sonrasında da 2019'daki durum değerlendirilmiştir. Böylelikle de ilçenin ne yönde bir gelişim sergilediği daha net anlaşılabilmektedir. 1985 yılı nüfus sayımından hareketle hazırlanan nüfus piramidine baktığımızda (Şekil 7); ilçede çocuk ve genç nüfusla birlikte genç yetişkinlerin sayısında da bariz bir üstünlük olduğu anlaşılmaktadır. Aynı yaş grubundaki erkeklerin ise kadınlardan daha fazla olduğu da dikkat çeken bir diğer noktadır. İlçede 0 - 24 yaş arasındaki nüfus toplam nüfusun $\% 62,5$ gibi önemli bir dilimini oluşturmuştur. Söz konusu yaş grubunun cinsiyete göre sayılarına baktığımızda toplam 45.520 erkeğe karşılık, 44.171 kadın sayılmıştır. Orta yaş grubunda ise kadın ve erkek sayısının görece daha dengeli olduğu görülmekle birlikte özellikle 60 yaş ve üzeri kitlede kadın sayısının erkek sayısından fazla olduğu dikkat çekmektedir. 1985'te Kozan'da 60 yaş ve üzeri 4.068 kadına karşıık, 3.420 erkek sayılmıştır. Kozan'ın 1985 yılına ait nüfus sayımına göre hazırlanan nüfus piramidi için doğum oranlarında dikkat çekici bir gerileme gözlenmiş, bununla 
birlikte ölüm oranlarında da düşüşün yaşandığı anlaşılmaktadır. Söz konusu dönem için bu durum Türkiye geneli dikkate alındığında büyük ölçüde paralellik gösteren bir durumdur.

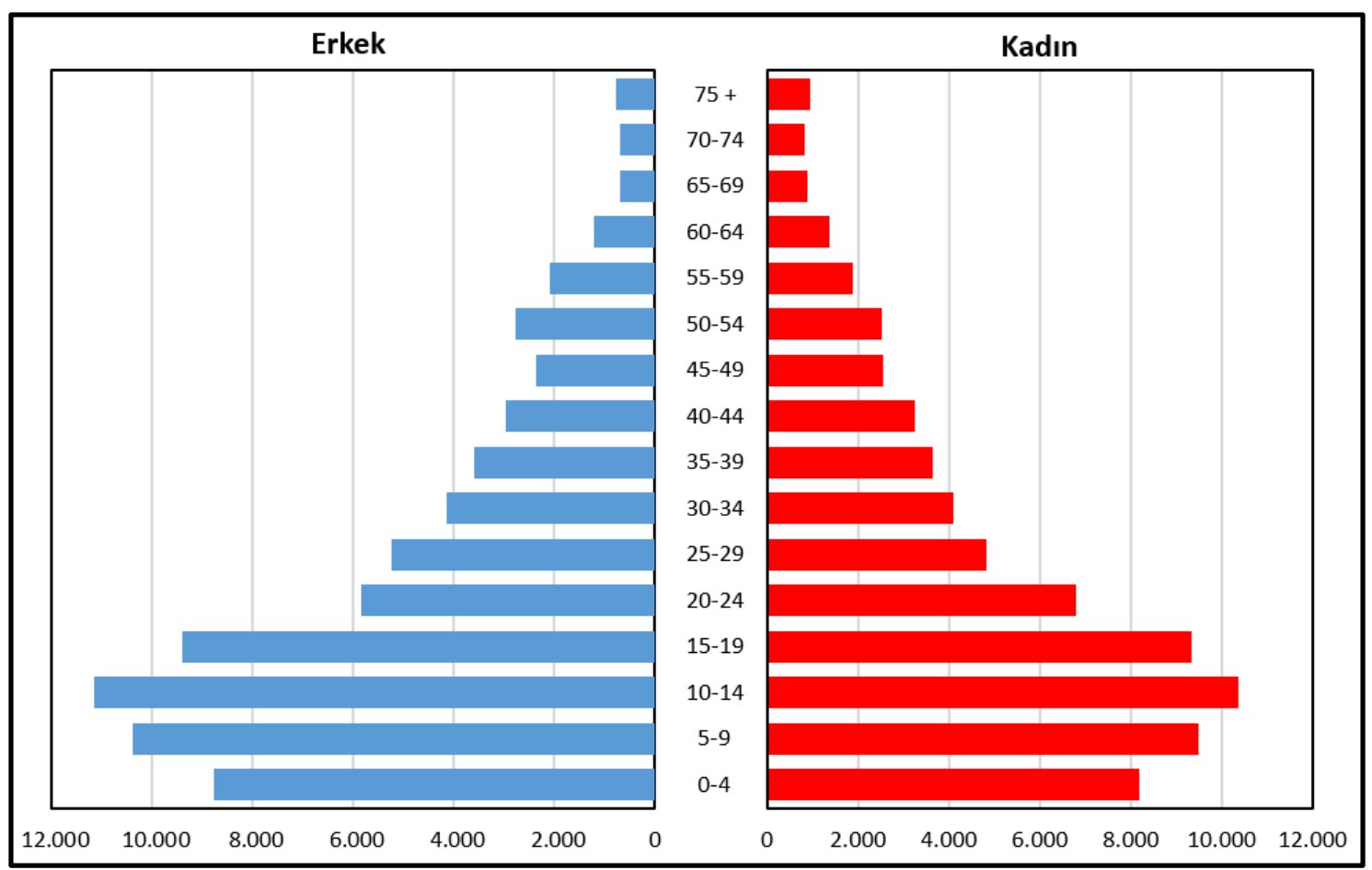

Şekil 7: 1985 Yılı Kozan İlçesi Nüfus Piramidi

Kozan'ın 2019 yılına ait nüfus piramidine baktığımızda ise nispeten gelişmiş ülkelerdekine benzer bir profil yakalandığını söyleyebiliriz. Doğum oranının düşüklüğüyle beraber ölüm oranında da azalmalar dikkat çekmektedir. Şekil 8'de de görüldüğü üzere ilçedeki en dikkat çekici husus 20 ile 34 yaş arasındaki genç/genç yetişkinlerin sayısındaki azalmadır. 2019 itibariyle Kozan'daki söz konusu yaş aralığındaki kişi sayısı toplam nüfusun sadece \%19,3'ünü oluşturmaktaydı. Bu yaş aralığındaki kişilerin sayısının azlığında eğitim ve iş amacıyla yapılan nüfus hareketleri büyük ölçüde belirleyici olmaktadır. İlçede önemli bir gelişmişlik göstergesi de 65 yaş ve üzeri nüfustaki artıştır. 2019 itibariyle ilçedeki 65 yaş üstü nüfusun (13.925 kişi), toplam nüfusa oranı $\% 10,5$ 'tir. İlerleyen yıllarda Kozan nüfusunun daha da yaşlanacağı için buna göre bir takım sosyal ve iktisadi yatırımlara yönelinmesi gerekecektir. Kozan şehrinin, yaşlanan nüfusunun refah seviyesine uygun bir şekilde tasarımı, ulaşım ve sağlık hizmetlerinin buna göre revizyonu ilerleyen süreçte yerel yönetimlerin gündemini en fazla meşgul edecek konular arasında yer almaktadır. 


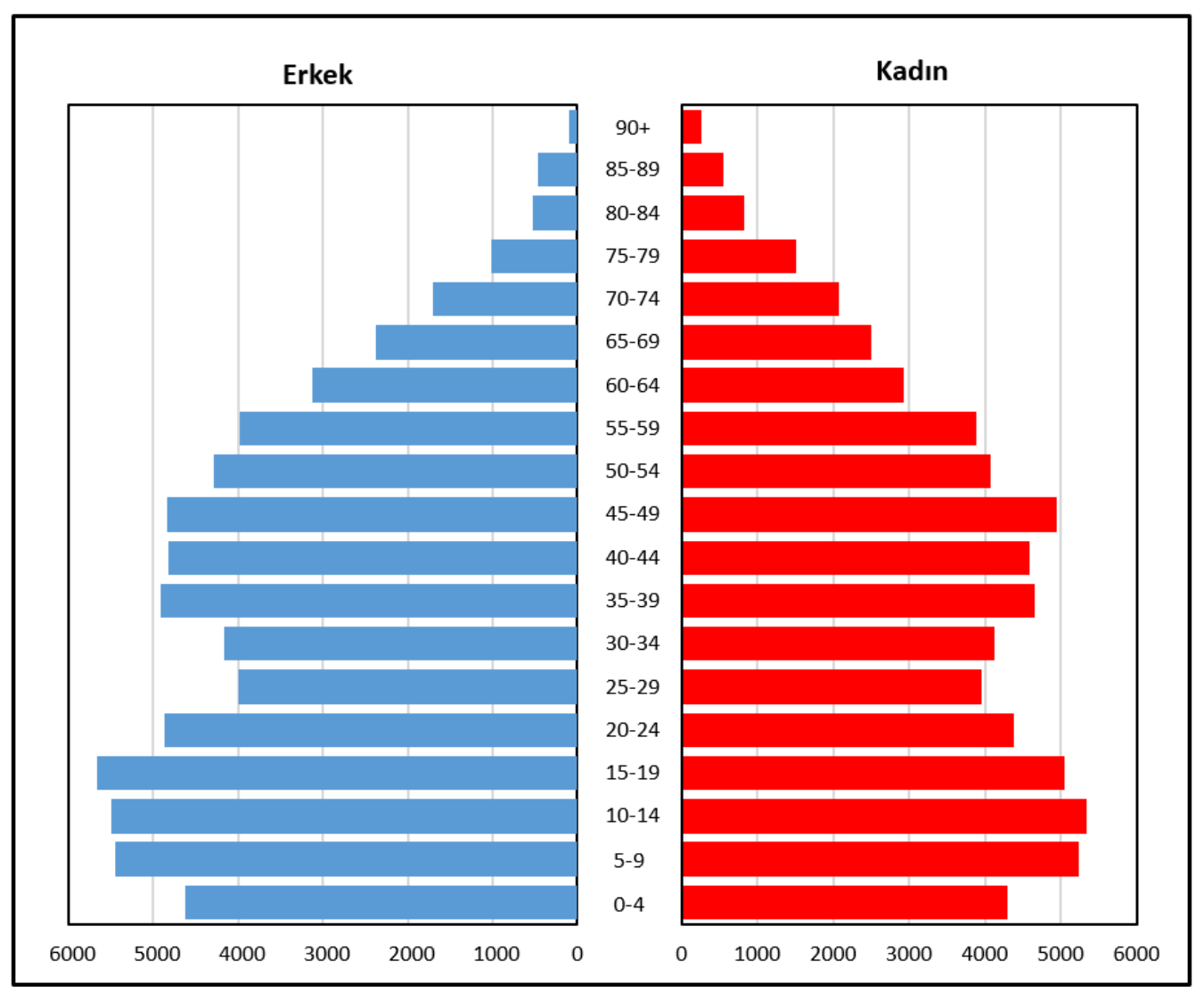

Şekil 8: 2019 Yılı Kozan İlçesi Nüfus Piramidi

b. Nüfusun Cinsiyet Yapısı ve Medeni Durumu: Bir yerdeki nüfusun cinsiyet durumu doğal şartlarda çoğu zaman birbiriyle dengeli bir yapı sergilemekle beraber bazı olağanüstü şartlar veya çoğunlukla iktisadi şartlar bu dengenin bozulmasına neden olmaktadır. Yaşanan savaşlar, seferberlik halleri, çalışma amacıyla yurt içi ve yurt dışına yapılan göçler çoğu zaman bazı sahalarda erkek nüfusunun azalmasına, bazı sahalarda da erkek nüfusun artmasına neden olmaktadır. Kozan ilçesi için de bu gibi şartların etkisinden bahsetmek mümkündür. İlçede Cumhuriyet'in ilk nüfus sayımının yapıldığı 1927 'den, II. Dünya Savaşı'nın olağanüstü şartlarına değin erkek kayıplarının fazlalığı ve silah altında bulunuyor oluşu nedeniyle 1927, 1935 ve 1940 yıllarında erkek nüfus kadın nüfusun gerisinde kalmıştır. Sonraları 1970 yılı istisna kabul edilirse 2000'lere değin bu defa tam tersi bir durum yaşanmış ve erkek sayısı, kadın sayısını geçmiştir. 1970'teki erkek sayısının azlığı ise Almanya başta olmak üzere yurtdışına işçi göçünün artmasından kaynaklanmıştır. 2000'lerde ise tablo 6'da da görüldüğü üzere seçilmiş yıllardan sadece 2007 yılında erkek sayısı, kadın sayısının gerisinde kalmış (2000 yılındaki çok küçük fark dikkate alınmamıştır), bu dönemde ise yine çoğunlukla erkeklerin 
gerek iş gerekse eğitim faaliyetlerine bağlı ilçe dışına çıkmalarıyla izah edilebilir. Öte yandan konuyla ilgili hazırlanan tablo 6 bir bütün olarak değerlendirilecek olduğunda esasında kadın ve erkek sayıları çoğu zaman birkaç yüzlük fark göstermiştir ki, bu da nüfusun doğal yapısı içerisinde olağan kabul edilebilir bir durumdur. Örneğin; 1945 yılı farkı 121 kişi, 1980 yılı farkı 80 kişi, 2000 yılı farkı ise sadece 5 kişidir.

\begin{tabular}{|c|c|c|c|c|c|c|c|}
\hline Yıllar & Kadın & Erkek & Toplam & Yıllar & Kadın & Erkek & Toplam \\
\hline 1927 & 13.683 & 13.003 & 26.686 & 1980 & 65.361 & 65.439 & 130.800 \\
\hline 1935 & 15.755 & 15.396 & 31.151 & 1985 & 71.114 & 72.259 & 143.373 \\
\hline 1940 & 17.923 & 17.829 & 35.752 & 1990 & 58.627 & 59.077 & 117.704 \\
\hline 1945 & 20.221 & 20.342 & 40.563 & 2000 & 65.440 & 65.435 & 130.875 \\
\hline $1950^{*}$ & - & - & - & 2007 & 62.210 & 61.770 & 123.980 \\
\hline 1955 & 31.681 & 32.259 & 63.940 & 2010 & 63.209 & 63.891 & 127.100 \\
\hline 1960 & 37.218 & 38.665 & 75.883 & 2012 & 63.687 & 64.239 & 127.926 \\
\hline 1965 & 45.606 & 47.279 & 92.885 & 2015 & 64.295 & 64.947 & 129.242 \\
\hline 1970 & 52.521 & 52.048 & 104.569 & 2019 & 65.195 & 66.438 & 131.633 \\
\hline 1975 & 57.425 & 58.254 & 115.679 & & & & \\
\hline
\end{tabular}

Tablo 6: Yıllar İtibariyle Kozan İlçesinde Kadın ve Erkek Sayıları (TÜİK, 2020)

İlçedeki kadın ve erkek sayılarındaki değişimin tarihsel süreçteki seyrini ele alırken esasında 1990'dan itibaren olan durumu ele almak bugün için daha sağıklı olacaktır. Kozan'da her ne kadar 1985'te kadın ve erkek sayıları tarihinin en yüksek seviyesine çıkmış olsa da İmamoğlu'nun ayrı bir ilçe olarak teşkilatlanmasıyla söz konusu sayıları 1990 'da erkeklerde 59.077, kadınlarda 58.627 olmuştur (Tablo 6). Söz konusu bu değerlerle ilçedeki kadın - erkek sayısı neredeyse 1975 'teki seviyesine inmiştir. Kozan'da kadın - erkek sayıları 2000'lerde kayda değer bir değişim göstermemiş, ilk olarak 2007'de yapılan ADNKS sonuçlarına göre kadınlarda 62.210, erkeklerde 61.770 olan sayı, 2019'a gelindiğinde kadınlarda \%4,8 ve erkeklerde de \%7,5 oranında artış göstermiştir. Buradan da bir kez daha anlaşıldığı üzere Kozan'da nüfus artış hızı, 1900'lerin ortalarıyla kıyasladığında oldukça yavaşlamıştır. Nitekim 10 yılı aşkın sürede \%10'u dahi bulmayan artış oranları, 1955'ten 1960'a değin olan süreçle kıyaslandığında sadece 5

* 1950 yılına ait genel nüfus sayımı neticelerine göre yıllıklarda ilçeler ölçeğinde cinsiyet yer almamıştır. 
yılda kadınlarda \%17,4, erkeklerde ise \%19,8 olması, artış hızı hakkında daha net fikir vermektedir.

Kozan ilçesinde nüfusun cinsiyet yapısıyla ilgili son olarak 2019 'daki duruma baktığımızda erkek sayısı 66.438, kadın sayısı ise 65.195 olmuştur. Söz konusu değerler Adana ölçeğinde değerlendirildiğinde şekil 9'da da görüldüğü üzere Kozanlı kadınlar, Adana kadın nüfusu içerisinde $\% 5,8$, erkekler ise $\% 5,9^{\prime}$ luk bir dilimi oluşturmaktadırlar. Bahis konusu oranlarıyla Adana genelinde 5. sırada yer alan Kozan için genel olarak kadın - erkek sayısı dengelidir diyebiliriz.

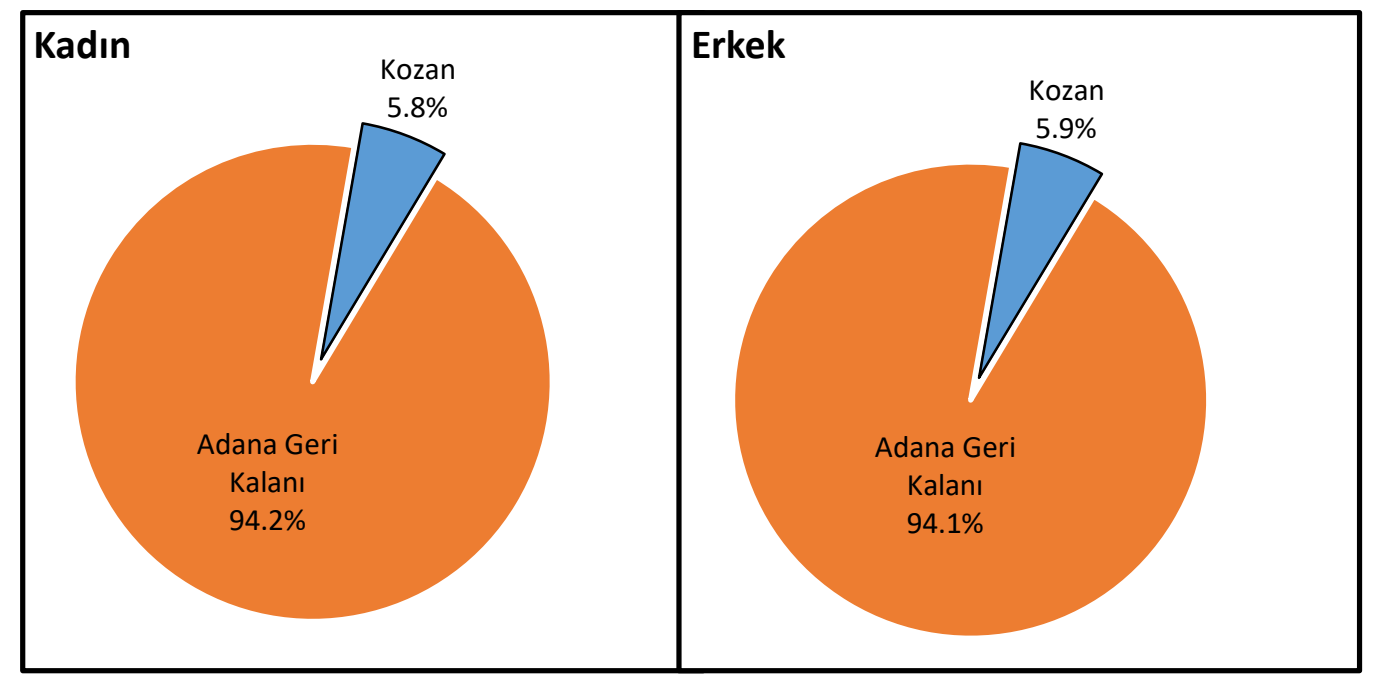

Sayfa | 131

Şekil 9: Kozan İlçesi Kadın ve Erkek Nüfuslarının 2019 İtibariyle Adana Toplamı İçerisindeki Oranları (TÜİK, 2020)

Kozan'da nüfusun medeni haline baktığımızda, seçilmiş yıllara göre düzenlenen tablo 7'de görüldüğü üzere nüfus miktarındaki artışa bağlı olarak evlilik sayılarında da olağan bir artış gözlenmektedir. Buna karşılık ilçede hiç evlenmemiş olanların sayısı önceki yıllara kıyasla gerilemiş, boşanma sayılarında ise birkaç katılık artış yaşanmıştır. Evli olanların sayısı 1990 'da 44.710 iken, 2000 'de 58.136'ya yükselerek, $\% 30$ oranında artmıştır. 2000'den 2010'a değin artış oranı ise \%3,9 ile sınırlı kalmış, 2010 - 2019 arasında ise çok küçük oranda artarak \%5,9 olmuştur. Evli olan kadın ve erkek nüfusu özellikle son yıllarda çok daha dengeli bir hal almıştır. Geçmişte daha çok erkeğin çalışmak için ilçe dışına çıkmasından kaynaklı olarak evli kadın sayısı erkeklerden fazla olmuştur. İlçedeki hiç evlenmeyenlerin sayısında ise çok daha farklı bir durum söz konusudur. 1990'da 34.333 olan sayı, 2000'de 36.750'ye yükselmiş, 2010'da ise 25.563 'e kadar inmiş, 2019'da da bir miktar artarak 27.008 olmuştur. Toplam nüfus içerisinde 1990 itibariyle 
$\% 29,1$ 'lik bir paya sahip olan hiç evlenmemiş nüfusun, 2019'daki payı ise $\% 20,5^{\prime}$ e gerilemiştir. Hiç evlenmemiş olan nüfus içerisinde bu defa belirgin bir şekilde erkek nüfus öne çıkmaktadır. Tablo 7 'de de görüldüğü üzere seçilmiş her yılda evlenmemiş erkek nüfus daha fazla olduğu gibi kadın - erkek nüfusu arasındaki fark da yıldan yıla açılmaktadır. Boşanmalarda ise 1990'daki duruma kıyasla birkaç katlık artış yanı sıra bu defa da 2019'daki durum istisna kabul edilirse kadın sayısında artışın olduğu dikkat çekmektedir. Kozan'da 1990'daki 428 boşanmış kişi sayısı 2000'de \%97 oranında artarak 844 olmuş, 2010'da 2.182 olan sayı 2019 'da 3.495'e çıkmıştır. Buna göre de ilçede 2000'den 2019'a değin boşanmış kişi sayısı \%300'ün üzerinde artış göstermiştir. Boşanmalardaki artışta kadınların toplum içerisindeki bireysellik haklarının daha fazla farkına varabilmeleri, eğitim seviyesindeki artış, kadınların eğitim hayatı ve kariyer planlamada erkeklerle aynı seviyeye gelmeye başlaması gibi sebepler ilk sıralarda yer almaktadır. Eşi vefat etmiş olan nüfusta da doğal bir gelişim olarak zaman içerisinde artışlar söz konusu olmakla birlikte cinsiyetler arasında çok dikkat çekici bir durum söz konusudur. Kozan'da eşi vefat etmiş kadın sayısı, erkeklerin sayısının birkaç katıdır. Örneğin; 1990'da eşi vefat eden toplam nüfus 3.122 olup bunun $\% 86,7$ 'sini kadınlar oluşturmaktadır. 2019'daki duruma baktığımızda da toplam 6.496 eşi vefat etmiş olan kişinin \%86'sı kadındır. Bu durum erkeklerin uzun soluklu ve de ağır işlerde, yıpratıcı şartlarda çalışması neticesinde ölüm oranlarının daha yüksek olmasıyla açıklanabilir. Nitekim ölüm sayılarının gösterildiği tablo 3'ten de hatırlanacağı üzere ölen erkek sayısı, her yıl kadınlardan daha fazla olmuştur.

\begin{tabular}{|c|c|c|c|c|c|}
\hline & & Evli & $\begin{array}{c}\text { Hiç } \\
\text { Evlenmemiş }\end{array}$ & Boşanmış & Eşi Ölmüş \\
\hline & & & 1990 & & \\
\hline & Erkek & 21.754 & 18.371 & 194 & 413 \\
\hline Kozan & Kadın & 22.956 & 15.962 & 234 & 2.709 \\
\hline & Toplam & 44.710 & 34.333 & 428 & 3.122 \\
\hline & & & 2000 & & \\
\hline & Erkek & 28.352 & 20.201 & 327 & 512 \\
\hline Kozan & Kadın & 29.784 & 16.549 & 517 & 3.405 \\
\hline & Toplam & 58.136 & 36.750 & 844 & 3.917 \\
\hline & & & 2010 & & \\
\hline Kozan & Erkek & 30.220 & 14.882 & 977 & 753 \\
\hline
\end{tabular}




\begin{tabular}{|l|l|l|l|l|c|}
\hline \multicolumn{1}{|c|}{} & Kadın & 30.205 & 10.681 & 1.205 & 4.763 \\
\cline { 2 - 6 } & Toplam & 60.425 & 25.563 & 2.182 & 5.516 \\
\hline \multirow{3}{*}{ Kozan } & Erkek & 32.011 & 16.119 & 1.752 & 909 \\
\cline { 2 - 6 } & Kadın & 32.003 & 10.889 & 1.743 & 5.587 \\
\cline { 2 - 6 } & Toplam & 64.014 & 27.008 & 3.495 & 6.496 \\
\hline
\end{tabular}

Tablo 7: Seçilmiş Yıllar İtibariyle Kozan Halkının Medeni Durumu* (Genel Nüfus Sayımları, 1990, 2000; ADNKS, 2020)

C. Nüfusun Eğitim Düzeyi: Kozan'da nüfusun eğitim yapısını izaha başlamadan evvel, kısaca ilçenin eğitim altyapısını izah edecek olursak 2020 itibariyle ilçede toplam 141 eğitim kurumunun 94'ü ilkokul (2'si özel), 31'i ortaokul (2'si özel) ve 16'sı da liseden müteşekkildir. Söz konusu kurumların toplam derslik sayısı 1.128 adet olup 1.929 öğretmen, 29.074 kayıtlı öğrenci bulunmaktadır. Derslik başına düşen öğrenci sayısı ilkokul ve ortaokullarda 23, liselerde 30, mesleki ve teknik liselerde ise 22'dir. Bunlar haricinde Kozan'da Çukurova Üniversitesi'ne bağlı Kozan Meslek Yüksekokulu bulunmakta olup 1993 - 1994 döneminde eğitim - öğretim faaliyetlerine başlamıştır. 2020 itibariyle Kozan Meslek Yüksekokulu'na kayıtlı 487 erkek, 369 kız olmak üzere toplam 856 kayıtlı öğrenci bulunmaktadır. İlçedeki Kozan Halk Eğitim Merkezi bünyesinde ise 17 derslik, 17 öğretmen ve kayıtlı 897 kursiyer bulunmaktadır.

Kozan nüfusunun eğitim durumuna baktığımızda zaman içerisinde çok dikkat çekici değişimlerin yaşandığı görülmektedir. Esasında Kozan'daki bu durum Türkiye'deki çoğu küçük şehir ve geniş kırsal nüfuslu kesimler için benzer niteliktedir. Örneğin; 1935 sayım sonuçlarına göre Kozan'da okuma yazma bilen toplam 3.660 kişinin 2.467 'si kırsal kesimde yaşayanlardan müteşekkildir ${ }^{\dagger}$. Söz konusu sayım dönemi için şehirli nüfusun 1.193'ü okuma yazma bilmektedir. Okur yazar sayısının bu dönemde kırsal kesimde daha fazla olmasında başlıca faktör şehirli nüfusun çok sınırlı olması ve de Cumhuriyet'in ilk yıllarında eğitim faaliyetlerine verilen büyük önem, okuma - yazma seferberliği, millet mektepleri gibi girişimlerle yoğun nüfuslu kırsal kesimde okur - yazar sayısında kayda değer artışlar yaşanmasına neden olmuştur. Her ne kadar 1935 verilerine göre kırsal kesimdeki

\footnotetext{
* 1990 ve 2000 yıllarına ait veriler 12 yaş üzeri nüfusu, geri kalan yıllar ise 15 yaş ve üzeri nüfusu kapsamaktadır.

+ Sadece okuma bilen 34 kişi toplam sayıya dahil edilmemiştir.
} 
okur yazar sayısı şehirdekilerden fazlaysa da okuma yazma bilmeyenlerin sayısı da yine kırsal kesimde çok fazladır. Aynı yıla ait verilere göre Kozan'da okuma yazma bilmeyen toplam 27.457 kişinin (\%86'sı) kırsal kesimde, geri kalanı (3.839 kişi) da şehirli nüfustan oluşmaktaydı. Yakın yıllara kadar tüm Türkiye için kronikleşmiş bir sorun olan kadın nüfusun okullaşma oranı ve genel olarak eğitim öğretim faaliyetlerine dahil olmada erkeklerin gerisinde kalınması Kozan için de söz konusu olmuştur. 1935 yılı verilerine göre şehirli nüfustan okuma yazma bilmeyen 3.839 kişinin 2.297'si $(\% 59,8)$ kadınlardan oluşmaktaydı. Kırsal kesimde okuma yazma bilenlerin ise sadece \%6,7 gibi küçük bir kısmını (248 kişi) kadınlar oluşturmaktaydı. Her ne kadar son yıllarda bu durum büyük ölçüde değişim göstermişse de okur yazarlıkta kadınlar hala erkeklerin gerisinde bulunmaktadır.

Daha yakın yıllara bakıldığında ise okullaşma seviyesi dikkat çekici ölçüde artmış olmakla beraber kadınların okullaşma oranlarında hala ciddi sıkıntıların söz konusu olduğu anlaşılmaktadır. Tablo 8'de görüldüğü üzere hem 2010'da hem de 2019'da ilköğretim / ilkokula giden öğrenci sayısı artmış, hatta kız çocuklarının ilkokula erkeklerden daha fazla kayıt oldukları görülmektedir. Ortaokul seviyesinde ise bu durum tersine dönmekte ve kız öğrencilerin sayıları erkek öğrencilerin ciddi manada altında kalmış görülmektedir. Benzer durum lise için de söz konusudur. Yüksek öğretimde de her ne kadar erkek sayısı kadın sayısından ciddi manada yüksek olsa da toplamda 2010'dan 2019'a değin bu alandaki öğrenci sayısı \%141 oranında artış göstermiştir. Kozan'da okula gitmediği halde okuma-yazma bilenlerin sayısı ile okuma-yazma bilmeyenlerin sayısında ise pozitif yönde gelişmeler söz konusu olup bu sayılarda önemli gerilemeler olmuştur. 2010'dan 2019'a değin ilçede okuma-yazma bilmeyenlerin sayıları \%54,7 oranında azalmıştır. Öte yandan okuma-yazma bilmeyenlerin önemli bir kısmını $(\% 87,1)$ yine kadınlar oluşturmaktadır. 


\begin{tabular}{|l|c|c|c|c|c|c|}
\hline \multirow{2}{*}{ Eğitim Düzeyi } & \multicolumn{3}{|c|}{$\mathbf{2 0 1 0}$} & \multicolumn{3}{c|}{$\mathbf{2 0 1 9}$} \\
\cline { 2 - 7 } & Erkek & Kadın & Toplam & Erkek & Kadın & Toplam \\
\hline İlköğretim & 9.734 & 8.539 & 18.273 & 5.133 & 4.364 & 9.497 \\
\hline İlkokul & 13.522 & 14.729 & 28.251 & 13.871 & 16.839 & 30.710 \\
\hline Ortaokul & 3.834 & 2.108 & 5.942 & 12.691 & 9.531 & 22.222 \\
\hline Lise veya dengi okul & 11.492 & 8.635 & 20.127 & 14.018 & 10.394 & 24.412 \\
\hline $\begin{array}{l}\text { Yüksekokul veya } \\
\text { Fakülte }\end{array}$ & 3.678 & 2.228 & 5.906 & 7.772 & 6.484 & 14.256 \\
\hline Yüksek Lisans & 156 & 80 & 236 & 548 & 323 & 871 \\
\hline $\begin{array}{l}\text { Doktora } \\
\text { Okuma-Yazma bilen } \\
\text { fakat okula gitmemiş } \\
\text { olanlar }\end{array}$ & 11.431 & 10.982 & 22.413 & 5.765 & 7.569 & 13.334 \\
\hline $\begin{array}{l}\text { Okur-Yazar } \\
\text { olmayanlar }\end{array}$ & 1.810 & 8.228 & 10.038 & 584 & 3.963 & 4.547 \\
\hline Bilinmeyenler & 1.872 & 1.496 & 3.368 & 242 & 215 & 457 \\
\hline
\end{tabular}

Tablo 8: Kozan'da 2010 ve 2019 Yılları İtibariyle Nüfusun Eğitim Durumu (ADNKS, 2020)

Kozan'da nüfusun yüksek öğretime katılma durumunu detaylandırdığımızda şekil 10'da da görüldüğü üzere toplamda olumlu bir gelişim içerisinde olduğu anlaşılmaktadır. İlçede 2008'den 2019'a değin lisans ve lisansüstü düzeyde mezun olanların sayısı \%200'ün üzerinde artış göstermiştir. Burada dikkat çeken durum ise özellikle kadın nüfusun üniversite eğitiminde erkeklerin çok gerisinde kalmış olduğudur. Birkaç yıla ait verilere baktığımızda da anlaşılacağı üzere; 2008 'de 2.921 erkeğe karşın sadece 1.600 kadın üniversite hayatına katılmıştır (Şekil 10). 2014'te de 5.975 erkek lisans ve lisansüstü eğitime dahil olurken aynı yıl 4.422 kadın söz konusu eğitim seviyelerinden mezun olmuştur. Son olarak 2019'da ise lisans ve üstündeki eğitim kademelerinden mezun olan kadın sayısı 6.825 iken, erkeklerde bu sayı 8.354 olmuştur. Her ne kadar kadınlarda bu alandaki sayı erkeklerin gerisinde olsa da yıldan yıla gerçekleşen artış erkeklerin çok üzerindedir. Nitekim kadınlarda 2008'den 2019'a değin lisans ve üzerindeki mezunlar sayısı \%326 oranında artış göstermişken aynı aralıkta erkeklerdeki oran \%186 artmıştır. 


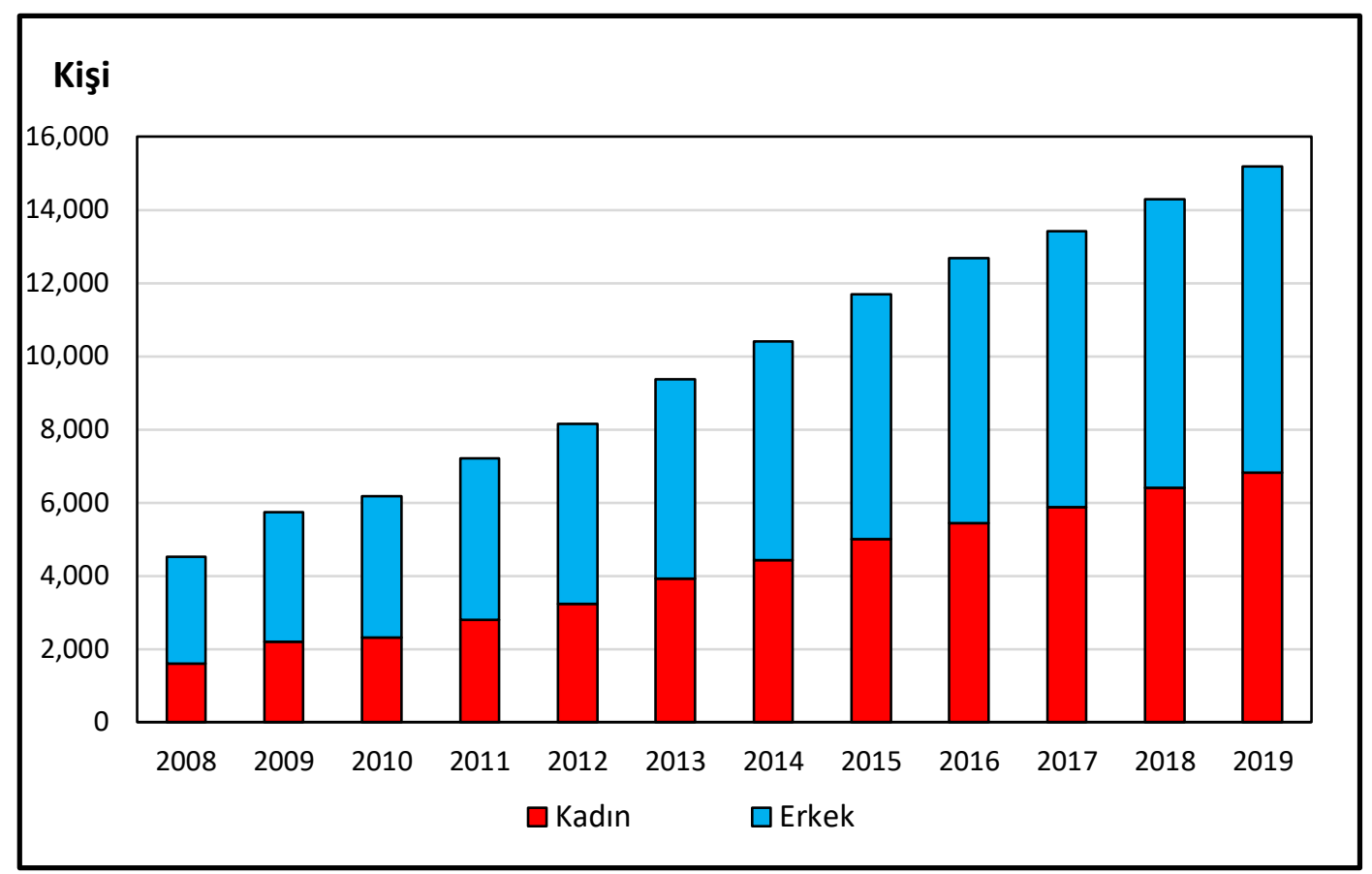

Şekil 10: Son 12 Yılda Kozan'da Cinsiyete Göre Lisans ve Lisansüstü Mezununun Nüfustaki Değişimi (ADNKS, 2020)

Lisansüstü mezun sayısında da yine kayda değer artışlar yaşanmıştır. Sadece lisansüstü kadın mezunlarda sayı 2008'de 42 iken 2010'a gelindiğinde 2 katından fazla bir artışla sayı 93 olmuş, 2015'te 163 'e yükselmiş ve 2019'da da 341 olmuştur. Erkeklerde de 2008'de lisansüstü mezun sayısı 71 iken 2011'de 197, 2015'te 287 ve son olarak 2019'da da 582 olmuştur (ADNKS, 2020). 2019 itibariyle bahis konusu eğitim düzeyi mezunlarının Adana'da ilçeler ölçeğindeki dağılımına baktığımızda ise Çukurova (12.464 kişi) ve Seyhan (9.045 kişi)'ın il genelinde yarıdan fazla bir dilimi kapsadığı görülmektedir (Şekil 11). Bu ilçeleri sırasıyla Yüreğir, Sarıçam, Ceyhan ve Kozan takip etmektedir. Kozan, 2019 itibariyle toplam 923 lisansüstü mezunuyla il genelinde 6. sırada yer almaktadır. Geri kalan 9 ilçe ise toplam lisansüstü mezunu sayısıyla (757 kişi) Kozan'ın gerisinde kalmışlardır. 


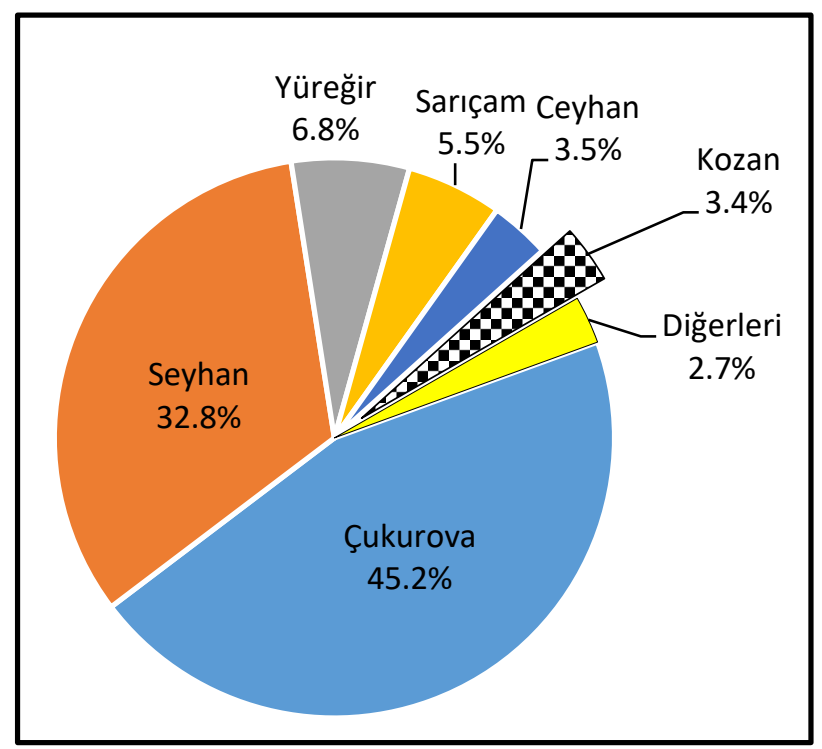

Şekil 11: 2019 İtibariyle Adana'da İlçelere Göre Lisansüstü Mezun Sayıları (ADNKS, 2020)

Kozan'da herhangi bir eğitim kurumundan mezun olmuş kitlenin ardından genel olarak ilçedeki okur-yazar olma durumu ve bunun Adana geneli ile mukayesesini incelediğimizde okur-yazar sayılarında pozitif yönde gelişme görülmektedir. Tablo 9'da görüldüğü üzere 1980 'den itibaren Adana geneli ve Kozan özelinde okur-yazar olmayan nüfusun toplam nüfus içerisindeki payı dikkat çekici ölçüde daralmış, 1980 'de $\% 25,5$ olan bu oran 2019'a gelindiğinde \%2,8'e gerilemiştir. Söz konusu gerileme özellikle erkek nüfusta çok daha belirgin olup Adana genelinde 1980 'de okur-yazar olmayan erkek nüfus oranı $\% 7,8$ iken, 1990 'da \%5,1'e, 2019'da da \%1'in de altına düşerek \%0,4 olmuştur (Tablo 9). Erkek nüfus içinde okur-yazar olanların oransal açıdan her zaman daha yüksek olmasında erkeklerin askerlik hizmeti kapsamında bu alanda temel düzeyde okuma-yazma eğitimi almaları da etkili olmaktadır. Öte yandan hem Adana hem de Kozan'da okuryazar olmayan kadın nüfus toplam içerisinde hala belli bir oranı korumakla birlikte bu oranın daralma hızı erkeklerinkinden daha düşüktür. Örneğin; Kozan'da 1980'de okur-yazar olmayan kadın sayısı 7.833 olup oransal değeri \%5,9 iken, 1990'a gelindiğinde sayı 6.065 kişi, oran ise $\% 5,1$ olmuştur. 


\begin{tabular}{|c|c|c|c|c|c|}
\hline & & Okur-Yazar & $\begin{array}{c}\text { Okur-Yazar } \\
\text { Olmayan }\end{array}$ & A ( $\%)$ & Bilinmeyen \\
\hline & & & 1980 & & \\
\hline & Erkek & 498.615 & 116.989 & 7.87 & 263 \\
\hline Adana & Kadın & 343.617 & 262.562 & 17.67 & 219 \\
\hline & Toplam & 842.232 & 379.551 & 25.54 & 482 \\
\hline & Erkek & 14.847 & 3.245 & 2.48 & 89 \\
\hline Kozan & Kadın & 9.811 & 7.833 & 5.98 & 83 \\
\hline & Toplam & 24.658 & 11.078 & 8.46 & 172 \\
\hline & & & 1990 & & \\
\hline & Erkek & 735.548 & 99.033 & 5.11 & 347 \\
\hline Adana & Kadın & 585.767 & 242.620 & 12.53 & 258 \\
\hline & Toplam & 1.321 .315 & 341.653 & 17.65 & 605 \\
\hline & Erkek & 21.664 & 2.453 & 2.08 & 12 \\
\hline Kozan & Kadın & 16.782 & 6.065 & 5.15 & 5 \\
\hline & Toplam & 38.446 & 8.518 & 7.23 & 17 \\
\hline & & & 2019 & & \\
\hline & Erkek & 982.331 & 9.013 & 0.40 & 6.276 \\
\hline Adana & Kadın & 944.743 & 55.188 & 2.46 & 6.553 \\
\hline & Toplam & 1.927 .074 & 64.201 & 2.86 & 12.829 \\
\hline & Erkek & 59.832 & 584 & 0.44 & 242 \\
\hline Kozan & Kadın & 55.522 & 3.963 & 3.01 & 215 \\
\hline & Toplam & 115.354 & 4.547 & 3.45 & 457 \\
\hline
\end{tabular}

A: Okur - Yazar olmayan nüfusun toplam nüfus içerisindeki oranı.

Tablo 9: Seçilmiş Yıllar İtibariyle Adana ve Kozan'da Nüfusun Okur-Yazar Düzeyi

2019'daki durumu detaylandıracak olduğumuzda bu defa 1980 ve 1990 yıllarından farklı bir durum karşımıza çıkmaktadır. Söz konusu her iki yılda da Adana genelinde okur-yazar olmayan nüfusun toplam nüfus içerisindeki payları Kozan'dakinden fazlayken, 2019'a gelindiğinde okur-yazar olmayan nüfusun toplam nüfus içerisindeki payı, Adana genelini geçmiştir. Başka bir ifadeyle okur-yazar seviyesindeki artış hızı Adana genelinde daha fazla olup Kozan'da bu hız yakalanamamıştır. Sonuçta 2019 itibariyle Adana genelinde okuryazar olmayan nüfusun toplam içerisindeki payı \%2,8 ile sınırlı kalmış olup Kozan'da bu oran \%3,4'tür. Bu yüksek oranda ise çok büyük 
ölçüde okur-yazar olmayan kadın nüfus etkili olmuş, bu da kadınların okullaşma oranlarının Kozan'da hala arzu edilir seviyeye çekilemediğini göstermektedir. 2019 itibariyle Adana'nın Seyhan ilçesinde okuma yazma bilmeyen kadın nüfusu 21.006, Yüreğir'de 14.136 ve bu açıdan 3. sırada yer alan Kozan'da da 3.963 kişidir (TÜİK, 2020). Aynı yıl toplam kadın nüfus bakımından 6. sırada olan ilçenin, söz konusu okuryazarlık durumunda 3 . sırada olması bu hususa ayrıca eğilinmesi gerektiğini göstermektedir.

\section{NÜFUSUN İSTİHDAM DURUMU}

Nüfus araştırmalarında tarihsel süreçte en fazla zorluk yaşanan kısım belli dönemlerde değişkenlik gösteren parametreler ve bunların süreklilik sağlamamasından ötürü yaşanan zorluklardır. İstihdam durumu, etnik yapı, inanç, anadil gibi bazı demografik göstergeler bazı sayımlarda yer alıyorken, bazılarında hiç ele alınmamış veya sorgulama şekli değişmiştir. İstihdam konusu da ele alınırken, Kozan için en önemli istihdam sahası olan zirai alan detaylandırılabilirken, diğer alanlarla ilgili belli yıllar esas alınarak çıkarımda bulunulmaya çalışılmıştır. İlk olarak 1927 itibariyle Kozan'daki istihdam durumunun ana çizgilerine baktığımızda 5.822'si erkek, 1.201'i kadın olmak üzere toplam 7.023 kişi istihdam edilmiş olup erkeklerin $4.875^{\prime} \mathrm{i}$, kadınların da 1.091'i ziraat alanında çalışmaktaydı (İstatistik Umum Müdürlüğü, 1929: 134). Başka bir ifadeyle erkeklerin \%83,7'si, kadınların da $\% 90,8$ 'i ziraat alanında istihdam olunmaktaydı. Buna göre de söz konusu dönem için Kozan ilçesinin temel iktisadi faaliyeti olarak ziraat öne çıkmaktadır. Aynı yıl Adana'da istihdam edilen toplam çiftçi sayısının \%25,6'sını Kozanlı çiftçiler oluşturmuştur. Takip eden yıllarda zirai alan en önemli istihdam alanı olma özelliğini korumaya devam etmiştir. Daha yakın yıllara doğru ilçedeki duruma baktığımızda toplam istihdam sayısında dikkat çekici oranda gerilemelerin yaşandığı dikkati çekmektedir. Örneğin; 1985 'te istihdam edilen toplam 60.313 kişi, 2000 'e gelindiğinde \%21 oranında gerileyerek 47.471 olmuştur (Tablo 10). Hem kadın hem de erkek istihdamındaki bu gerilemede özellikle eğitime yönelmenin büyük etkisi olmuştur. Nitekim ilgili tabloda da görüldüğü üzere işgücünde olmayan nüfus 1990'a kıyasla önemli ölçüde artmıştır. Bu durumu da detaylandıracak olursak; 2000'de işgücünde olmayan toplam 45.905 kişinin \%36,3'ü öğrencilerden, $\% 40,6$ 'sı ev hanımlarından, \%9,4'ü de emeklilerden oluşmaktadır. Geri kalanlar ise türlü nedenlerle bu gruba dahil olan kişilerdir. Burada yeri gelmişken işaret edilmesi gereken bir nokta da Kozan'da nüfusun yaş 
yapısının değerlendirildiği bölümde de belirtildiği üzere ilerleyen yıllarda işgücüne dahil olmayan nüfustaki emeklilerin, paylarının çok daha genişleyecek olduğudur. İlçedeki işsiz sayısındaki gelişime baktığımızda ise bu alanda da bir artış yaşanmış olup 1985'te 644 kadın işsizken bu değer $\% 171$ artarak 2000 'de 1.748 olmuş; erkeklerde ise söz konusu dönemler için \%32,5 artış göstermiştir. Kadın işsizlerdeki bu artış, özellikle eğitime yönelen kadın sayısının artmasına karşılık söz konusu kitleyi istihdam edecek sahaların oluşturulamamasından ileri gelmektedir.

\begin{tabular}{|l|c|c|c|c|}
\hline & İstihdam & İşsiz & İşgücünde Olmayan & Bilinmeyen \\
\hline \multicolumn{5}{|c|}{1985} \\
\hline Erkek & 34.682 & 3.415 & 10.445 & 120 \\
\hline Kadın & 25.631 & 644 & 22.917 & 87 \\
\hline Toplam & 60.313 & 4.059 & 33.362 & 207 \\
\hline \multicolumn{5}{|c|}{1990} \\
\hline Erkek & 28.745 & 3.307 & 8.639 & 43 \\
\hline Kadın & 22.116 & 1.265 & 18.455 & 25 \\
\hline Toplam & 50.861 & 4.572 & 27.094 & 68 \\
\hline \multicolumn{5}{|c|}{2000} \\
\hline Erkek & 27.486 & 4.527 & 17.382 & 2 \\
\hline Kadın & 19.985 & 1.748 & 28.523 & - \\
\hline Toplam & 47.471 & 6.275 & 45.905 & 2 \\
\hline
\end{tabular}

Tablo 10: Seçilmiş Yıllar İtibariyle Kozan'da Nüfusun İşgücüne Göre Dağılımı (TÜİK, $1985,1990,2000$ )

Kısaca Kozan'daki zirai duruma, hem demografik hem de iktisadi açıdan yeri geldikçe dikkat çekilmiş olup özellikle Büyükşehir Yasası ile birlikte yaşanan değişime de işaret edilmiştir. İstihdam durumunda da bu konu ayrıca dikkat çekici bir noktadadır. Daha önce de bahsedildiği gibi zirai alandaki istihdam Kozan'ın en önemli iş sahası durumundadır. Tablo 11 'den de anlaşıldığı üzere hem toplam istihdamın hem de kırsal nüfusun yarıdan fazlasını zirai kesimdeki istihdam oluşturmaktadır. Toplam istihdam içerisinde zirai alandaki istihdam 1985 ve 2000 yıllarında \%70'in üzerinde kaldığı gibi, 1980'de neredeyse \%80'e yaklaşmıştır. 1990'da kısmen de olsa gerilemenin olduğu bu sektör yine de önemini korumuştur. Hemen her yılda kadın istihdamının da çok büyük bir oranını zirai kesim oluşturmuş olup 1985'te bu oran \%95,3 iken, 1990'da \%86, 2000'de de \%90,6 olmuştur. Erkekler ise iş 
hayatında kadınlardan daha çeşitli alanlarda ve de daha fazla istihdam edilmelerinden ötürü oranları az olsa bile yine de 2000'e gelindiğinde istihdam edilen tüm erkeklerin \%59,3 gibi azımsanmayacak bir oranı zirai kesimde istihdam edilmiştir. Konuyu sadece kırsal kesim nüfusu odağında incelersek, yine tablo 11 'de görüldüğü üzere kırsal kesim nüfusunun yarıdan fazlası zirai kesimde istihdam edilmiş durumdadır. 2000 'e doğru bu değerin artması ise hem kayıt dışı çalışan tarım işçilerinin kayıt altına alınması hem de toplam kırsal kesim nüfusunun azalmasıyla bu kesimde çoğunlukla çalışanların kalmasıyla alakalıdır. Ayrıca yine kırsal kesim nüfusu içerisinde de kadınların oransal olarak erkeklerden daha fazla bu alanda istihdam olunduğu görülmektedir.

\begin{tabular}{|l|c|c|c|c|c|}
\hline & $\begin{array}{c}\text { Toplam } \\
\text { İstihdam }\end{array}$ & $\begin{array}{c}\text { Zirai } \\
\text { Alandaki } \\
\text { İstihdam }\end{array}$ & A (\%) & Kırsal Nüfus & B (\%) \\
\hline \multicolumn{5}{|c|}{$\mathbf{1 9 8 5}$} \\
\hline Erkek & 34.682 & 23.609 & 68.0 & 46.146 & 51.1 \\
\hline Kadın & 25.631 & 24.449 & 95.4 & 46.903 & 52.1 \\
\hline Toplam & 60.313 & 48.058 & 79.7 & 93.049 & 51.6 \\
\hline \multicolumn{5}{|c|}{1990} \\
\hline Erkek & 28.745 & 15.971 & 55.5 & 31.003 & 51.5 \\
\hline Kadın & 22.116 & 19.024 & 86.0 & 32.250 & 58.9 \\
\hline Toplam & 50.861 & 34.995 & 68.8 & 63.253 & 55.3 \\
\hline & 2000 \\
\hline Erkek & 27.486 & 16.302 & 59.3 & 27.273 & 59.7 \\
\hline Kadın & 19.985 & 18.116 & 90.6 & 27.769 & 65.2 \\
\hline Toplam & 47.471 & 34.418 & 72.5 & 55.042 & 62.5 \\
\hline
\end{tabular}

A: Toplam istihdam içerisinde zirai alandaki istihdamın payı.

B: Kırsal nüfus içerisinde zirai alanda istihdam olan nüfusun payı.

Tablo 11: Seçilmiş Yıllar İtibariyle Kozan'ın Zirai Alandaki İstihdamı ve Oransal Değerleri (TÜİK, 1985, 1990, 2000)

Burada hem Kozan'daki kırsal nüfus konusunun daha iyi anlaşılabilmesi hem de istihdam açısından ilçenin temel iktisadi faaliyetleri arasında yer alan tarım ve diğer kırsal kesim ekonomilerini kısaca irdelemek gerekir. Kozan yüzölçümü açısından Adana'da 1. sırada, toplam tarım alanı varlığı bakımından da Ceyhan ve Yüreğir'in 
ardından 3. sırada yer almaktadır. Kozan'da geçmişten beri önemli bir yer tutan zirai faaliyetlere bağlı olarak ilçe için temel iktisadi faaliyet olarak tarımın öne çıkması normaldir. Bununla birlikte zaman içerisinde ilçenin tarımsal yapısında da değişiklikler olmuştur. Örneğin geçmişte azımsanmayacak bir pamuk üretimi söz konusuyken zamanla üretimi önemli ölçüde azalmıştır. Turunçgiller noktasında ise bu alandaki faaliyetin daha da yoğunlaştığı dikkati çeker hale gelmiştir. İlçedeki belli başı tarımsal göstergeleri Adana ile kıyasladığımızda ise il genelindeki toplam tarım alanlarının \%12'si Kozan'da bulunmaktadır. Aynı şekilde tarla bitkileri alanlarının da \%12,1'lik kısmı, turunçgillere bağı olarak meyve, içecek ve baharat bitkileri alanlarının da \%14'e yakını Kozan'a aittir (Tablo 12). Bitkisel üretim açısından bakıldığında ise 2019 'da Kozan'daki 85.856 tonluk mısır üretimiyle il toplamının \%12'ye yakın kısmını sağlamış olup buğdayda (Durum hariç) bu oran \%16'ya yaklaşmıştır. İlçede yetiştirilen bitkiler içerisinde yonca (Yeşil ot) ise yaygın olarak Kozan'da yetiştirilmekte olup bu üründe $\% 29,8$ 'lik bir payı bulunmaktadır. İlçenin 10.888 tonluk soya fasulyesi $(\% 12,1)$ ve 8.243 tonluk yerfıstığı $(\% 9,1)$ üretimiyle de belli bir hacmi bulunmaktadır. Daha öncede belirtildiği gibi Kozan'da pamuk ziraatı önemli ölçüde gerilemiş olup 2019'daki sınırlı üretimiyle Adana genelinde \%2'lik bir payı söz konusu olmuştur. Meyveler özelinde baktığımızda ise Adana'nın önemli turunçgil merkezlerinden biri olarak karşımıza çıkan Kozan'ın, 2019 itibariyle 52.803 tonluk portakal (Washington) üretimi ile \%38'lik payı dikkat çekicidir (Tablo 12). Limon üretimi ise aynı yıl 18.219 ton olup $\% 6,4$ 'lük payı bulunmaktadır. İlçede 2000 'lerin ikinci yarısından yakın yıllara değin önemli bir artış gösteren nar, son birkaç yılda pazar sorunu ve üretim fazlası gibi nedenler ve bundan kaynaklı sökümlerle kısmen gerilemişse de son 6 yılda 3 bin tonun altına inmemiştir. Hayvancılık ve ormancılık bir kenara bırakıldığında Kozan için hala zirai faaliyetin önemli bir yer tuttuğu anlaşılmaktadır. Fakat mevcut düzenlemeyle birlikte söz konusu üretim değerleri ve tarımsal potansiyeline karşılık kırsal kesim nüfusunun 0 (sıfır) kabul edilmesi, nüfus yorumlamalarında, aynı zamanda da iktisadi planlamada güçlük olarak karşımıza çıkmaktadır.

\begin{tabular}{|l|l|c|c|c|}
\hline & \multicolumn{1}{|c|}{$\begin{array}{c}\text { Zirai } \\
\text { Göstergeler }\end{array}$} & Adana & Kozan & $\begin{array}{c}\text { Kozan'ın } \\
\text { Payı (\%) }\end{array}$ \\
\hline Alan (da.) & $\begin{array}{l}\text { Toplam tarım } \\
\text { alanı }\end{array}$ & 4.767 .252 & 572.093 & 12.0 \\
\hline
\end{tabular}




\begin{tabular}{|l|l|c|c|c|}
\hline & $\begin{array}{l}\text { Tarla bitkileri } \\
\text { alanı }\end{array}$ & 3.557 .337 & 430.406 & 12.1 \\
\cline { 2 - 5 } & $\begin{array}{l}\text { Meyve, içecek ve } \\
\text { baharat bitkileri }\end{array}$ & 785.261 & 109.074 & 13.9 \\
\cline { 2 - 5 } & Sebze alanı & 335.445 & 16.710 & 4.9 \\
\hline & Mısır & 717.802 & 85.856 & 11.9 \\
\cline { 2 - 5 } & $\begin{array}{l}\text { Buğday (Durum } \\
\text { hariç) }\end{array}$ & 502.378 & 80.250 & 15.9 \\
\cline { 2 - 5 } & Soya fasulyesi & 89.594 & 10.888 & 12.1 \\
\cline { 2 - 5 } & Yerfıstığı & 90.424 & 8.243 & 9.1 \\
\cline { 2 - 5 } & Yonca (Yeşil ot) & 19.780 & 5.904 & 29.8 \\
\cline { 2 - 5 } & $\begin{array}{l}\text { Pamuk } \\
\text { (Çıçırlanmamış, } \\
\text { kütlü) }\end{array}$ & 205.670 & 4.228 & 2.0 \\
\cline { 2 - 5 } & Karpuz & 867.919 & 34.725 & 4.0 \\
\cline { 2 - 5 } & $\begin{array}{l}\text { Limon, misket } \\
\text { limonu }\end{array}$ & 283.786 & 18.219 & 6.4 \\
\cline { 2 - 5 } & $\begin{array}{l}\text { Portakal } \\
\text { (Washington) }\end{array}$ & 138.871 & 52.803 & 38.0 \\
\hline Nar & 71.066 & 3.909 & 5.5 \\
\hline
\end{tabular}

Tablo 12: 2019 Yılı İtibariyle Adana ve Kozan'da Seçilmiş Zirai Göstergeler

(TÜİK, 2020)

Konuyla ilgili son olarak 2019'daki duruma baktığımızda Kozan Sosyal Güvenlik Merkez Müdürlüğü verilerine göre ilçede 16.103 sigortalı çalışan bulunmaktadır. Bunların da 3.447'si memur olup geri kalanlar özel sektör çalışanlarından oluşmaktadır. Aynı yıl ilçede toplam 11.438 emekli (2.349'u memur emeklisi) bulunmaktadır ki, neredeyse emekli sayısı çalışan sayısına yaklaşmıştır. Aynı yıl Kozan İlçe Tarım ve Orman Müdürlüğü verilerine göre ÇKS'ye kayıtlı toplam 5.284, 2020 itibariyle de 5.427 üretici bulunmaktadır. Bundan hareketle de 2019 için Kozan'da 21.136 civarında kişinin geçimini zirai faaliyetlerden sağladığını söyleyebiliriz. Bu değer de 2019 yılı Kozan toplam nüfusunun \%16'sına karşılık gelmektedir. Burada dikkat çekilmesi gereken bir diğer nokta da zirai alanda faaliyet gösteren herkesin ÇKS'ye kayıtlı olmadığı, sektörden uzmanlarla yapılan görüşmelerle de \%25 ila \%30'luk bir kesimin daha kayıt dışı olduğu anlaşılmıştır. Buna göre ise Kozan'da en iyimser tahminlerle 6.500 ila 7.000 arasında kişi zirai alanda istihdam edilmekte olup buna göre de 26 - 28 bin kişi geçimini bu alandan sağlamaktadır. Burada Adana'nın çoğu yerinde 
olduğu gibi Kozan'daki mevsimlik tarım işçilerine de dikkat çekmek gerekir. Özellikle yöre için portakal hasat zamanı başta olmak üzere yerfıstığı sökümü ve yakın yıllara kadar da pamuk hasadı için Güneydoğu Anadolu Bölgesi illeri başta olmak üzere (Çoğunlukla Şanlıurfa'dan) ilçeye doğru bir nüfus akışı olmaktaydı. Son yıllarda ise mevsimlik tarım işçisi olarak yaygın bir şekilde Suriye'den gelen mülteciler istihdam edilmeye başlanmıştır. Bu durum ise yılın belli dönemlerinde Kozan'da ciddi bir nüfus hareketliliği yaşanmasına neden olmaktadır.

\section{KOZAN'DA NÜFUS HAREKETLERİ}

Adana geneli göz önüne alındığında nüfus hareketliliği bakımından Kozan'ın kısmen daha farklı bir yapı sergilediği anlaşılmaktadır. Adana, Türkiye'nin farklı illerinden göç alan bir metropol olmasına karşın Kozan'da bu durumun etkisi fazla görülmemektedir. Hatta genel olarak Kozan nüfusunun çok büyük bir kısmını yine Kozanlıların oluşturduğunu ifade edebiliriz. Örneğin; tablo 13 'te 2010 ve 2019 yıllarına ait Kozan'da ikamet edenlerin kayıtlı oldukları illere baktığımızda 2010'da toplam nüfusun \%93,8'i, 2019'da ise \%92,8'ini Adana kayıtılır oluşturmaktadır ki bunun da büyük bir kısmını Kozanlıların teşkil ettiğini ifade edebiliriz. Kozan'da \%10'u dahi bulmayan diğer illere kayıtlı olanların ise büyük bir kısmını memurlar ve öğrenciler oluşturmaktadır. Burada belirtilmesi gereken bir diğer husus da Kozan'ın özellikle komşu illerle çok daha yakın nüfus ilişkileri olduğudur. Özellikle de başta Osmaniye olmak Kayseri, Kahramanmaraş ve Mersin kayıtlılar Kozan'daki diğer önemli nüfus kitlesini oluşturmaktadır. İlçede Osmaniye kayıtlılar geçmişten beri Adana kayıtılıardan sonra en büyük kitleyi oluşturmuştur. Komşu iller haricinde Kozan'a en fazla gelenler Güneydoğu Anadolu Bölgesi illerinden olmuştur.

\begin{tabular}{|l|c|c|}
\hline İler & $\mathbf{2 0 1 0}$ & $\mathbf{2 0 1 9}$ \\
\hline Adana & 119.202 & 122.190 \\
\hline Osmaniye & 2.360 & 2.589 \\
\hline Kayseri & 1.041 & 1.237 \\
\hline Kahramanmaraş & 550 & 638 \\
\hline Mersin & 343 & 477 \\
\hline Hatay & 317 & 450 \\
\hline Şanlıurfa & 327 & 415 \\
\hline
\end{tabular}




\begin{tabular}{|l|c|c|}
\hline Diyarbakır & 318 & 347 \\
\hline Adıyaman & 289 & 290 \\
\hline Gaziantep & 207 & 283 \\
\hline Niğde & 139 & 190 \\
\hline Mardin & 163 & 171 \\
\hline Konya & 128 & 158 \\
\hline Elazı̆̆ & 126 & 153 \\
\hline Malatya & 139 & 152 \\
\hline Sivas & 80 & 109 \\
\hline Ağrı & 105 & 100 \\
\hline
\end{tabular}

Tablo 13: Kozan'da İkamet Edenlerin Nüfusa Kayıtlı Oldukları İllerin 2010 ve 2019'daki Değerleri* (ADNKS, 2020)

Nüfusa kayıtlı olunan yerde olduğu gibi Kozan'da ikamet edenlerin doğum yerlerine baktığımızda da pek farklı bir durum karşımıza çıkmamaktadır. Bu açıdan bakıldığında da Adana doğumlular ilk sırada olup ilçede 2019 itibariyle yaşayanların \%91'ini Adana doğumlular teşkil etmektedir. Adana'yı sırasıyla 2.869 kişiyle Osmaniye, 1.165 kişiyle Kayseri, 659 kişiyle Mersin ve 600 kişiyle de Hatay takip etmektedir (Tablo 14). Buna göre Kozan'da ikamet edenlerin \%95,6'sı Adana ve komşu illerde doğmuştur. Komşular içerisinde Kozan nüfusunda en az etkisi olan yer ise Niğde'dir. Nüfusa kayıtlı olunan yerlerdeki durumdan farklı olarak doğum yerleri bakımından bu defa sınırlı da olsa İstanbul (343 kişi) ve Ankara (252 kişi)'da yer almaktadır. Bunlardan başka yine Güneydoğu Anadolu Bölgesi illerinde doğmuş olanların da sınırlı bir oranı bulunmaktadır.

\begin{tabular}{|l|c|l|c|}
\hline İller & Kişi Sayısı & İller & Kişi Sayısı \\
\hline Adana & 119.901 & Ankara & 252 \\
\hline Osmaniye & 2.869 & Diyarbakır & 233 \\
\hline Kayseri & 1.165 & Adıyaman & 208 \\
\hline Mersin & 659 & Konya & 198 \\
\hline Kahramanmaraş & 651 & Sivas & 196 \\
\hline Hatay & 600 & Malatya & 166 \\
\hline Yurtdışı & 527 & Antalya & 153 \\
\hline
\end{tabular}

\footnotetext{
* 100 kişi ve üzerindeki değere sahip illere yer verilmiştir.
} 


\begin{tabular}{|l|l|l|l|}
\hline Bilinmiyor & 438 & Niğde & 137 \\
\hline Gaziantep & 425 & İzmir & 112 \\
\hline İstanbul & 343 & Elazığ & 111 \\
\hline Şanlıurfa & 325 & \multicolumn{2}{|l}{} \\
\hline
\end{tabular}

Tablo 14: 2019 İtibariyle Kozan'da İkamet Edenlerin Doğum Yerleri (ADNKS, 2020)

Kozan dışına olan göç durumuna baktığımızda ise esasında Kozan'ın yerli halkının ilçe ve il dışına fazla çıkmadıkları dikkat çekmektedir. Bu durumda zaten bir büyükşehir olan Adana'nın çoğu ilçesi için imkanları karşılıyor olması en önemli faktör olmuştur. Sağlık, eğitim, iş imkanları bakımından Adana'nın halkın ihtiyacının büyük bir kısmını tatmin ediyor olması, dışarıya olan göçü kısıtlamıştır. Nitekim tablo 15'e bakıldığında seçilmiş tüm yıllar için Kozan'a kayıtlı olan nüfusun çok büyük bir kısmının Adana'da yaşıyor olması dikkat çekicidir. Tarihi ve kültürel bağları açısından Osmaniye'de ikamet edenleri de bu sayıya dahil edersek Kozanlıların genel manada Adana dışına fazlaca çıkmadıkları dikkat çekmektedir. Çok sınırlı olarak Kozan dışında yaşayanlar ise yine seçilmiş her yılda Ankara, İstanbul ve Mersin üst sıralarda yer almıştır. Burada yeri gelmişken belirtilmesi gereken önemli bir nokta da Kozan'a kayıtlı olup Kozan dışında yaşayanların kayda değer bir kısmı da komşu illerde yaşamaktadır. Örneğin; 2019'da komşu illerde yaşayan Kozanlıların sayısı 14.848'dir. Bu da Ankara ve İstanbul'un toplamından daha fazladır.

\begin{tabular}{|l|c|c|c|}
\hline İler & $\mathbf{2 0 1 0}$ & $\mathbf{2 0 1 5}$ & $\mathbf{2 0 1 9}$ \\
\hline Adana & 166.571 & 171.848 & 174.775 \\
\hline İstanbul & 5.304 & 6.739 & 7.570 \\
\hline Ankara & 3.456 & 4.526 & 5.113 \\
\hline Mersin & 4.220 & 4.599 & 4.978 \\
\hline Antalya & 2.334 & 3.118 & 3.581 \\
\hline Osmaniye & 2.313 & 2.861 & 3.254 \\
\hline Hatay & 2.080 & 2.267 & 2.473 \\
\hline Konya & 849 & 1.142 & 2.242 \\
\hline İzmir & 1.665 & 1.947 & 2.121 \\
\hline Kayseri & 1.265 & 1.683 & 1.892 \\
\hline Gaziantep & 929 & 1.363 & 1.509 \\
\hline Kahramanmaraş & 1.145 & 1.334 & 1.397 \\
\hline Bursa & 761 & 905 & 1.066 \\
\hline
\end{tabular}


Not: Sıralama 2019 yılına göre yapılmış ve 1.000 ile üzerindeki kişilerin bulunduğu iller dahil edilmiştir.

Tablo 15: Seçilmiş Yıllara Göre Kozan'a Kayıtlı Olan Nüfusun Türkiye'deki Dağılımı

(ADNKS, 2020)

Türkiye genelinde Kozan nüfusuna kayıtlı olan kişi sayısı 2019 itibariyle 226.761 kişi olup söz konusu kayıtlı kişilerin $174.775^{\prime} \mathrm{i}$ Adana'da yaşamaktadır (TÜİK, 2020). Aynı yıl Kozan nüfusuna kayıtlı 51.986 kişi ise Adana dışında ikamet ediyor olup söz konusu bu değer 2019 Kozan nüfusunun \%39,5'lik kısmına tekabül etmektedir. Başka bir ifadeyle 2019 itibariyle Kozan nüfusuna kayıtlı kişilerin kabaca \%40 kadarı Kozan / Adana dışında yaşamaktadır. Kozan nüfusuna kayıtı kişilerin 2019 itibariyle Türkiye'deki dağılımına baktığımızda ilk olarak bölgeler ölçeğinde incelersek şekil 12 'de de görüldüğü üzere Kozanlıların çok büyük bir kısmı Akdeniz Bölgesi dışına çıkmamıştır. Türkiye'deki 226.761 Kozanlı'nın \%84,3'lük kesimi Akdeniz Bölgesi'nde ikamet etmektedir. Bu bölgeyi birbiri ile hemen hemen aynı miktarda Kozanlı'ya sahip olan İç Anadolu ve Marmara Bölgesi takip etmektedir. Diğer bölgelerdeki Kozanlı sayısı çok düşük miktarda olup Doğu Anadolu ile Karadeniz Bölgeleri bu açıdan en düşük paya sahip bölgelerdir. Bölgesel dağılımdan da anlaşıldığı üzere Kozanlıların kendi bölgeleri dışına çıkmayı pek tercih etmedikleri anlaşılmaktadır. 


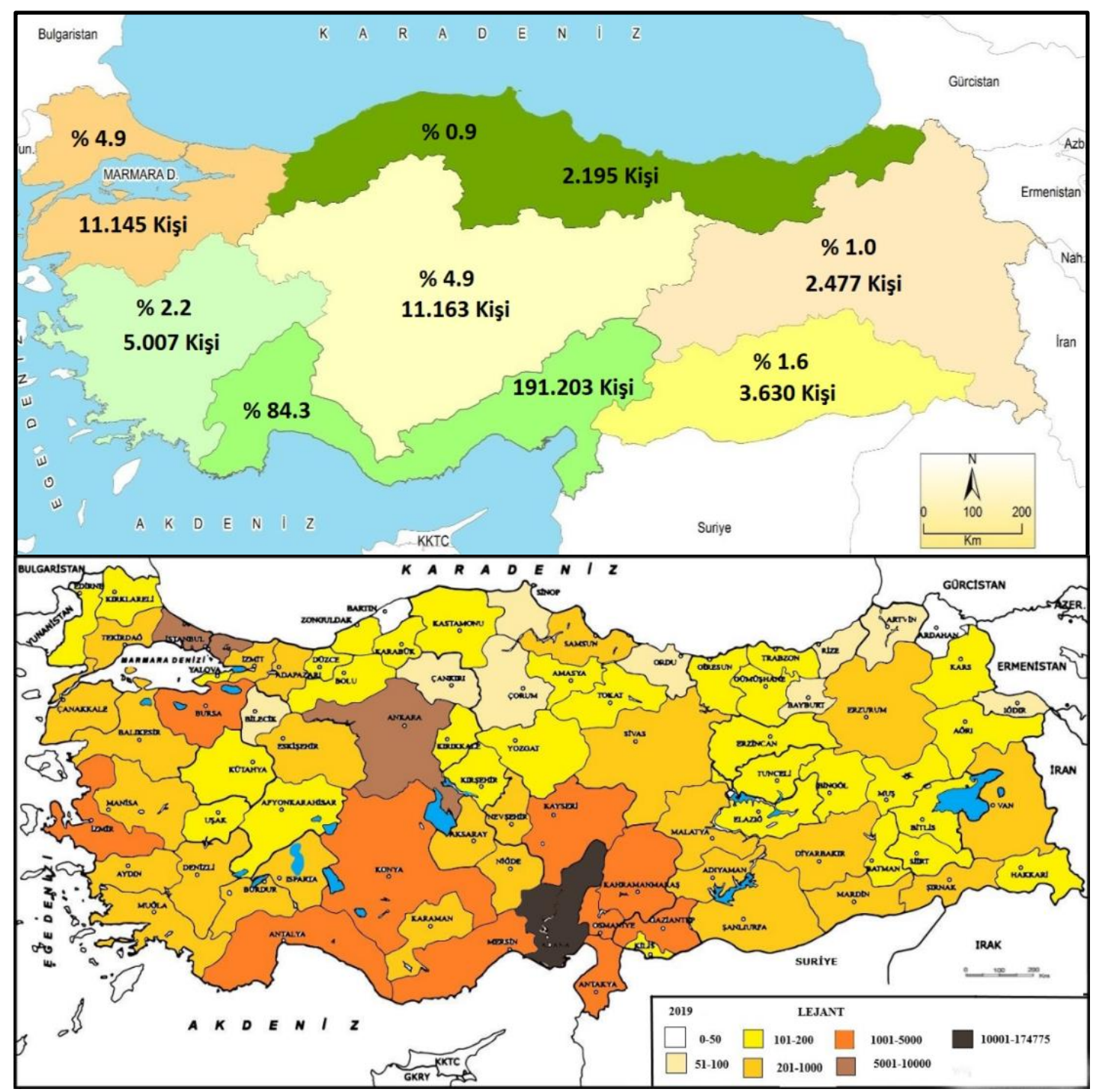

Şekil 12: 2019 İtibariyle Kozan Nüfusuna Kayıtlı Nüfusun Bölge ve İllere Göre Dağılımı

Kozanlıların iller ölçeğindeki dağılımına baktığımızda Akdeniz Bölgesi'ndeki asıl yoğunluk merkezini Adana'nın oluşturduğu anlaşılmaktadır. Buradan da Kozan dışına çıkan yerli halkın ikamet amaçlı yine Adana il genelini tercih ettikleri anlaşılmaktadır (Şekil 12). Sağlık, eğitim, iş ve diğer türlü hizmet ya da geçim sağlama amaçlı olanakları Adana'nın sağlamasından kaynaklı olarak halk için önemli bir cazibe merkezi olma özelliğini koruduğunu söyleyebiliriz. Adana'yı bir kenara bırakacak olursak İstanbul ve Ankara gibi 2 büyük cazibe merkezi dikkat çekmektedir. Öte yandan Adana'nın komşularında kayda değer Kozanlı sayısı belirgin bir şekilde ortaya çıkmaktadır. Ankara, İstanbul ve komşu iller haricinde Konya, Antalya, Bursa ve İzmir'de de 2 bin ila 3 bin civarında Kozanlı yaşamaktadır. Sınırlı da 
olsa Türkiye'nin hemen her ilinde yaşayan Kozanlıların büyük bir kısmı memuriyet ve eğitim sebebiyle farklı yerlerde ikamet etmektedirler.

Son olarak nüfus hareketleri denildiğinde sadece şehirlerarası göç değil türlü gerekçelerle kısa veya uzun süreli her türlü ikamet değişikliği akla gelmektedir. Kozan'ın da içinde bulunduğu Adana ve çevresi, uzun yıllar mevsimlik yaylak ve kışlak hareketleri ile mevsimlik tarım işçileri göçüne sahne olmuştur. 20. yüzyılın ortalarına değin Adana'nın ovalık kesimleriyle yüksek kesimleri arasında kayda değer bir kısım halkın yaylak ve kışlak arasında yer değiştirmesi oldukça yaygındı. Yürütülen politikalar ve değişen yaşam koşullarıyla bu durum zaman içerisinde oldukça azalmış, 1980'lerden itibaren ise bu gibi mevsimlik göçer halkın sayısı çok ciddi ölçüde azalmıştır. 1997 Köy Envanter Etüdü'ne göre de toplam 86 köyün nüfusu 57.899'u yerleşik, 6.153 'ü de yerleşik olmayan kişilerden oluşmaktaydı. Başka bir ifadeyle toplam kırsal kesim nüfusunun sadece $\% 9,6$ 'sını yerleşik olmayan halk teşkil etmekteydi.

\section{SONUÇ}

Sınırları belli bir sahanın her türlü demografik göstergelerle ele alınması, o sahayla ilgili kısa, orta ve de uzun vadede sağlıklı yatırımların yapılması, kaynakların (Özellikle de kaynaklar sınırlıysa) çok daha sağlıklı bir şekilde yönetilmesi ve de yönlendirilmesi açısından büyük yarar sağlamaktadır. Bütünüyle Cumhuriyet Dönemi ve kısmen de Osmanlı İmparatorluğu'nun son yılları ölçeğinde incelemiş olduğumuz Kozan ilçesinin demografik yapısının analizi de bu noktada belli çıkarımlar yapmamızı sağlamıştır. Sadece nüfusun gelişim seyri ve de son yıllardaki durum göz önüne alındığında;

- Kozan, yaş yapısı bakımından gelişmiş ülkeler seviyesine yaklaşmaktadır,

- İlçe nüfusu yaşlanmaktadır,

- Kozan halkının genelde ilçe/il dışına çıkmadığı görülmektedir,

- Kadın nüfusun istihdam ve okur-yazar olma durumu hala erkeklere kıyasla negatif durumdadır,

- Kadınların yine de geçmişe kıyasla okullaşma oranı artmış, iş hayatına daha çok dahil olmuşlardır,

- İstihdam noktasında kayıt dışı üreticiler hala azımsanmayacak seviyededir, 
- Evlilikler ile birlikte boşanmalar da önemli ölçüde artmış, bekar sayısı ise genel olarak azalma eğilimi göstermektedir,

- İlçede nüfus oldukça dengesiz bir dağılım sergilemektedir,

- Geçmişe kıyasla konar-göçer yaşam tarzı çok büyük ölçüde terkedilmiştir,

- İlçede hala en önemli geçim kaynağı kırsal kesim faaliyetleridir, sonuçları ortaya çıkmıştır. Söz konusu çıkarımlardan hareketle de;

- İlçe nüfusunun yaşlanmasından ötürü Kozan'da söz konusu kitleye uygun ulaştırma, sosyal hizmet (Hasta bakımı, yaşlıların ev temizliği, kişisel bakım gibi), hobi olanakları ve diğer sosyalleşme yapıları tesis edilmeli ve/veya düzenlenmelidir,

- Çoğunlukta Kozan'da kalmayı tercih eden yerli halka yönelik kaynakların sürdürülebilirliği, artan taleplere yönelik kaynakların etkili yönetimi büyük önem taşımaktadır. Hem iktisadi hem de sosyal açıdan yatırımlara ağırlık verilmelidir,

- Okur-yazar olmayan kadın nüfus sayısını azaltmak adına eğitim faaliyetleri (Akşam liseleri, Halk Eğitim Merkezleri vs.) alanında çalışmalar başlatılmalıdır,

- Kadınlara yönelik yeni istihdam sahaları yaratılmalı, özellikle eğitimli kadın nüfus kaynağının kullanım alanları tesis edilmelidir. Kozan ölçeğinde turizme yönelik yatırımlar ve istihdam sahası oluşturulması çok avantajlı görülmektedir,

- Kırsal kesim faaliyetleri ve buradaki halkın geçimi noktasında daha sıkı bir kayıt ve denetim mekanizması tesis edilmelidir,

- Kozan'daki mevsimlik tarım iş̧̧ilerinin, ilçede bulundukları geçici süre boyunca hem kendileri hem de yerli halk için rahatsızlık teşkil etmeyecek şekilde organize edilmeleri gerekir,

- Boşanmalardaki dikkat çekici artış göz önüne alındığında yerel yönetimce Aile Danışmanlığı Merkezleri yaygınlaştırılıp, buralara yönlendirme adına kamu spotları oluşturulması ilk etapta yapılması gerekenler olarak işaret edilebilir.

Kozan'ın ulaşım (Adana - Kozan - Kadirli - Osmaniye Demiryolu Projesi gibi), sanayi ve tarım alanında tümüyle sürdürülebilir bir gelişim özelinde planlanması, buranın sahip olduğu tabii ve kültürel miras ile bir bütün şeklinde düşünülerek yatırımların yönlendirilmesi ilçe 
nüfusunun refah seviyesi açısından büyük önem taşımaktadır. Hali hazırda ilçenin sahip olduğu köklü kültürel miras, turizm noktasında neredeyse çok zayıf bir şekilde değerlendirilmekte, hatta bazı noktalarda değerlendirilememektedir. Halbuki turizmin ilçe için önemli bir istihdam sahası ve gelir kaynağı olabileceği aşikardır. İlçe turizmi sadece kültürel mirasla sınırlı kalmayacak olup doğa turizmi (Dağılcak Tabiat Parkı gibi), agro-turizm, yayla turizmi gibi turizmin pek çok kolundan kaynağından bulunmasından ötürü büyük bir potansiyeli haizdir.

\section{KAYNAKÇA}

Akbal, F. (1951). 1831 Tarihinde Osmanlı İmparatorluğunda İdari Taksimat ve Nüfus. Belleten, Ankara: Türk Tarih Kurumu, Cilt: XV, 60, 617-628.

Aydın, H. (2019). Adana Vilayeti Salnamelerine Göre Kozan Livası, Aksaray Üniversitesi Sosyal Bilimler Enstitüsü. (Basılmamış Yüksek Lisans Tezi). Aksaray Üniversitesi, Aksaray.

Balcı Akova, S. (2004). Alanya İlçesi Nüfusunun Genel Özellikleri, Alanya Tarih ve Kültür Seminerleri III. 255-260, Antalya, Türkiye.

Başbakanlık İstatistik Genel Direktörlüğü. (1937). 20 İlkteşrin 1935 Genel Nüfus Sayımı / Kati ve Mufassal Neticeler: Seyhan Vilayeti, Türkiye Cumhuriyeti Başbakanlık İstatistik Genel Direktörlüğü, Neşriyat Sayısı: 75, Cilt: 48, 132, Ankara.

Bulut, İ. (2000). Yozgat'ın Nüfus Coğrafyası Özellikleri. Doğu Coğrafya Dergisi 6(4), 19-54.

Buyruk, H. (2011). Sis'i (Kozan) Akdeniz'den Kapadokya'ya Bağlayan Kervan Yolu Kaleleri. (Basılmamış Doktora Tezi). Atatürk Üniversitesi Sosyal Bilimler Enstitüsü, Sanat Tarihi Anabilim Dalı, Erzurum.

Cuinet, V. (1891). La Turquie d'Asie: Géographie Administrative, Statistique, Descriptive et Raisonnée de Chaque Province de l'AsieMineure, (Ed. Ernest Leroux), pp. 883, Paris.

Çanak, E. \& Yeşil, A. (2015). Atatürk Döneminde Adana (Seyhan) Vilayetinin Demografik Yapısı. Tarihin Peşinde, Uluslararası Tarih ve Sosyal Araştırmalar Dergisi 14, 101-128.

Darkot, B. (1993). Sis. İslam Ansiklopedisi Cilt. 10, İstanbul: MEB, 708-712.

Doğan, M. (2011). Türkiye'de Uygulanan Nüfus Politikalarına Genel Bakış. Marmara Coğrafya Dergisi, 293-307. 
Doğanay, H. (2014). Türkiye Beşeri Coğrafyası. Genişletilmiş ve Güncellenmiş 4. Baskı. Ankara: Pegem Akademi.

DİE. (1983). 12.10.1980 Genel Nüfus Sayımı / Nüfusun Sosyal ve Ekonomik Nitelikleri: 01 - Adana, Başbakanlık Devlet İstatistik Enstitüsü, Yayın No: 990-52, 88, Ankara.

DİE. (1987). 20.10.1985 Genel Nüfus Sayımı / Nüfusun Sosyal ve Ekonomik Nitelikleri: 01 - Adana, Başbakanlık Devlet İstatistik Enstitüsü, Yayın No: 1237, 128, Ankara.

DİE. (1993). 1990 Genel Nüfus Sayımı / Nüfusun Sosyal ve Ekonomik Nitelikleri: 01 - Adana, Başbakanlık Devlet İstatistik Enstitüsü, Yayın No: 1579, 160, Ankara.

DİE. (2002). 1997 Köy Envanteri / 01 Adana, T.C. Başbakanlık Devlet İstatistik Enstitüsü, Yayın Numarası: 2525, 143, Ankara.

Ertunç, H. (1991). Kozan İ/çesinin Beşeri ve Ekonomik Coğrafyası / Nüfus, Yerleşme ve Ekonomik Özellikleri. (Basılmamış Yüksek Lisans Tezi), İstanbul Üniversitesi Sosyal Bilimler Enstitüsü, İstanbul.

Göney, S. (1976). Adana Ovaları I., İstanbul Üniversitesi Yayın No: 2162, Coğrafya Enstitüsü Yayın No: 88, İstanbul.

Halaçoğlu, Y. (1993). Cebelibereket. İslam Ansiklopedisi Cilt: 7, 185186 , İstanbul.

Harita Genel Müdürlüğü. (2014). İl ve İ/çe Yüzölçümleri. Erişim Adresi: https://www.harita.gov.tr/images/urun/il ilce alanlari.pdf Erişim Tarihi: 31.10.2020.

Hasgül, S. (2016). Salnâmelere Göre Adana Vilâyeti'nin Demografik ve Kültürel Yapısı (Adana Merkez, Kozan, Cebel-i Bereket, İçel ve Mersin Sancağı). (Basılmamış Yüksek Lisans Tezi). Mersin Üniversitesi Sosyal Bilimler Enstitüsü, Mersin.

İdikurt, D. (2011). Osmanlıdan Cumhuriyet'e Bir Âyanlık Örneği: Kozanoğulları ve Fırka-i İslâhiye'nin Kuruluşu. (Basılmamış Yüksek Lisans Tezi). Nevşehir Üniversitesi Sosyal Bilimler Enstitüsü, Nevşehir. İstatistik Umum Müdürlüğü, (1929). 28 Teşrinievel 1927 Umumi Nüfus Tahriri, İstatistik Umum Müdürlüğü Neşriyatından: 7, Fasikül: 1, Ankara.

İstatistik Genel Müdürlüğü, (1961). 23 Ekim 1955 Genel Nüfus Sayımı, Türkiye Cumhuriyeti Başbakanlık İstatistik Genel Müdürlüğü, Yayın No: 412, Ankara. 
Kara, H. (1989). Cumhuriyete Kadar Çukurova Nüfusu, Coğrafya Araştırmaları Dergisi (Atatürk Kültür, Dil ve Tarih Yüksek Kurumu, Coğrafya Bilim ve Uygulama Kolu Yayını) 1(1), 115 - 122.

Karpat, K. H. (2003). Osmanlı Nüfusu (1830 - 1914) / Demografik ve Sosyal Özellikleri. (Çev.). Bahar Tırnakcı, İstanbul: Tarih Vakfı Yurt Yayınları.

Sertkaya Doğan, Ö. (2017). Saray'ın Nüfus Özellikleri, Memleket Pusulası Saray. (Ed.). Özlem Sertkaya Doğan. İstanbul: EBY Yayınları. Sertkaya Doğan, Ö. \& Şahin, G. (2019). Women's Presence in Turkey's Rural Population, $7^{\text {th }}$ International Conference on Gender Studies: Gender, Space, Place \& Culture, 10-12 October 2019, FamagustaNorth Cyprus.

Sümer, F. (1963). Çukur-Ova Tarihine Dâir Araştırmalar (Fetihten XVI. Yüzyılın İkinci Yarısına Kadar). Tarih Araştırmaları Dergisi 1(1), 1-98.

Şahin, G. \& Taşlıgil, N. (2019). Bolu İlinde Nüfusun Gelişimi ve Nüfus Hareketleri (1927 - 2018). Turkish Studies 14(5), 2515-2545.

Şaşmaz, M. (2014). Türkiye'nin İdari Taksimatı (1920 - 2013), I. Cilt, Atatürk Kültür, Dil ve Tarih Yüksek Kurumu. Ankara: Türk Tarih Kurumu Yayınları.

Taşlıgil, N. (1993). Kastamonu İlinin Nüfus Gelişimi ve Türkiye Nüfus Hareketleri İçerisindeki Yeri. Türk Coğrafya Dergisi 28, 215-224.

Tezölmez, A. N. (2018). Meşrutiyet'ten Cumhuriyet'e Adana'da Nüfus Hareketleri (1876 - 1923). (Basılmamış Yüksek Lisans Tezi), Harran Üniversitesi Sosyal Bilimler Enstitüsü, Şanlıurfa.

Tutar, A. (2002). XIX. Yüzyılın Sonlarında Kozan Sancağında Müslümanlar ve Gayrimüslimler, Dini Araştırmalar 5(13), 149-163.

TÜİK. (2020). Genel Nüfus Sayımları: 1965, 1970, 1975, 1980, 1985, 1990, 2000. Erişim Adresi:

https://biruni.tuik.gov.tr/nufusmenuapp/menu.zul Erişim Tarihi: 31.10.2020.

TÜİK. (2020). Bitkisel Üretim İstatistikleri. Erişim Adresi: https://biruni.tuik.gov.tr/medas/?kn=92\&locale=tr Erişim Tarihi: 31.10.2020.

Ünal, A. \& Girginer, K. S. (2007). Kilikya - Çukurova İlk Çağlardan Osmanlılar Dönemi'ne Kadar Kilikya'da Tarihi Coğrafya, Tarih ve Arkeoloji. İstanbul: Homer Yayınları. 
Yılmaz, M. (2016). Türkiye'nin Değişen Nüfus Yapısı: Nedenler, Değişim, Sonuçlar ve Gelecek. İstanbul: Çantay Kitabevi.

Zangger, E. \& Mutlu, S. (2016). Luviler: Bir Anadolu Uygarlığı ile İlgili Çalışmalar. idil 5(24), 1037-1078.

\section{Web Kaynakları:}

http://www.kozan.bel.tr/?/kozan1

http://www.kozan.gov.tr/kozan-ilcesinin-tarihi

https://kozan.tr.gg/

https://archives.eure.fr/

http://www.kozan.gov.tr/

GENIŞSETİLMIŞ ÖZET: Kozan; konumu, topografik, hidrografik ve klimatik özellikleriyle Bereketli Hilal'in (Fertile Crescent) bir parçası olmuş ve buna bağlı olarak da medeniyet tarihi binlerce yılı aşan önemli bir yerleşim birimi olmuştur. Tarihin pek çok döneminde siyasi, dini, askeri ve iktisadi önemini korumayı başarmış olan Kozan'ın sadece Türkiye açısından değil dünya medeniyet tarihi açısından da çok özel bir merkez olduğunun altı çizilmelidir. Cumhuriyet Devri'ne kadar "Sis" adıyla bilinen Kozan, günümüzde büyük ölçüde bitkisel üretim içerisinde turunçgiller başta olmak üzere bahçecilik, hayvancılık ve ormancılık ile geçimini sağlayan, küçük ve orta ölçekli sınırlı bir sanayisi bulunan bir ilçedir. Nüfus özellikleri bakımından incelediğimiz Kozan'da 1927 - 1985 ile 1990 - 2019 yılları arasında değerlendirebileceğimiz 2 dönem söz konusudur. İlçede 1927 'den sonra nüfus $1985^{\prime}$ e değin düzenli ve hızlı bir şekilde artıyorken, sonrasında (İmamoğlu'nun ayrımasını takiben) ilçe nüfusu çok daha yavaş bir hızla artış göstermeye başlamıştır. İlçenin coğrafi şartları buranın iskan, imar ve nüfus hareketleri üzerinde büyük ölçüde belirleyici olmuştur. Karakteristik Akdeniz ikliminin hakim olduğu Kozan'da, bataklıkların varlığı ve her yaz şiddetini artıran sıtma salgını gibi faktörler, burada uzun bir süre geniş nüfus kitlelerinin konar - göçer bir hayat sürmesine neden olmuştur. Öyle ki, yörenin ileri gelenleri dahi, yazları yaylalara çıkmakta, ancak havalar soğumaya başlayınca ovalık sahaya dönmekteydiler. Osmanlı İmparatorluğu'nun son yılları ile Cumhuriyet Dönemi'nin ilk yıllarında ise bataklıkların kurutulması, konar-göçerlerin yerleşik hayata teşviki, narenciye tarımının yaygınlaştırıması gibi unsurlar Kozan'ın günümüzdeki sosyo-ekonomik yapısını kazanmasında büyük rol oynamıştır. Sınırları belli bir sahanın her türlü demografik göstergelerle ele alınması, o sahayla ilgili kısa, orta ve de uzun vadede sağlıklı yatırımların yapılması, kaynakların (Özellikle de kaynaklar sınırlıysa) çok daha sağlıklı bir şekilde yönetilmesi ve de yönlendirilmesi açısından büyük yarar sağlamaktadır. Bütünüyle Cumhuriyet Dönemi ve kısmen de Osmanlı İmparatorluğu'nun son yılları ölçeğinde incelemiş olduğumuz Kozan ilçesinin demografik yapısının analizi de bu noktada belli çıkarımlar yapmamızı 
sağlamıştır. Sadece nüfusun gelişim seyri ve de son yıllardaki durum göz önüne alındığında;

- Kozan, yaş yapısı bakımından gelişmiş ülkeler seviyesine yaklaşmaktadır,

- İlçe nüfusu yaşlanmaktadır,

- Kozan halkının genelde ilçe/il dışına çıkmadığı görülmektedir,

- Kadın nüfusun istihdam ve okur-yazar olma durumu hala erkeklere kıyasla negatif durumdadır,

- Kadınların yine de geçmişe kıyasla okullaşma oranı artmış, iş hayatına daha çok dahil olmuşlardır,

- İstihdam noktasında kayıt dışı üreticiler hala azımsanmayacak seviyededir,

- Evlilikler ile birlikte boşanmalar da önemli ölçüde artmış, bekar sayısı ise genel olarak azalma eğilimi göstermektedir,

- İlçede nüfus oldukça dengesiz bir dağılım sergilemektedir,

- Geçmişe kıyasla konar-göçer yaşam tarzı çok büyük ölçüde terk edilmiştir,

- İlçede hala en önemli geçim kaynağı kırsal kesim faaliyetleridir, sonuçları ortaya çıkmıştır. Söz konusu çıkarımlardan hareketle de;

- İlçe nüfusunun yaşlanmasından ötürü Kozan'da söz konusu kitleye uygun ulaştırma, sosyal hizmet (Hasta bakımı, yaşlıların ev temizliği, kişisel bakım gibi), hobi olanakları ve diğer sosyalleşme yapıları tesis edilmeli ve/veya düzenlenmelidir,

- Çoğunlukta Kozan'da kalmayı tercih eden yerli halka yönelik kaynakların sürdürülebilirliği, artan taleplere yönelik kaynakların etkili yönetimi büyük önem taşımaktadır. Hem iktisadi hem de sosyal açıdan yatırımlara ağırlık verilmelidir,

- Okur-yazar olmayan kadın nüfus sayısını azaltmak adına eğitim faaliyetleri (Akşam liseleri, Halk Eğitim Merkezleri vs.) alanında çalışmalar başlatılmalıdır,

- Kadınlara yönelik yeni istihdam sahaları yaratılmalı, özellikle eğitimli kadın nüfus kaynağının kullanım alanları tesis edilmelidir. Kozan ölçeğinde turizme yönelik yatırımlar ve istihdam sahası oluşturulması çok avantajlı görülmektedir,

- Kırsal kesim faaliyetleri ve buradaki halkın geçimi noktasında daha sıkı bir kayıt ve denetim mekanizması tesis edilmelidir, 
- Kozan'daki mevsimlik tarım işçilerinin, ilçede bulundukları geçici süre boyunca hem kendileri hem de yerli halk için rahatsızlık teşkil etmeyecek şekilde organize edilmeleri gerekir,

- Boşanmalardaki dikkat çekici artış göz önüne alındığında yerel yönetimce Aile Danışmanlığı Merkezleri yaygınlaştırılıp, buralara yönlendirme adına kamu spotları oluşturulması ilk etapta yapılması gerekenler olarak işaret edilebilir.

Kozan'ın ulaşım (Adana - Kozan - Kadirli - Osmaniye Demiryolu Projesi gibi), sanayi ve tarım alanında tümüyle sürdürülebilir bir gelişim özelinde planlanması, buranın sahip olduğu tabii ve kültürel miras ile bir bütün şeklinde düşünülerek yatırımların yönlendirilmesi ilçe nüfusunun refah seviyesi açısından büyük önem taşımaktadır. Hali hazırda ilçenin sahip olduğu köklü kültürel miras, turizm noktasında neredeyse çok zayıf bir şekilde değerlendirilmekte, hatta bazı noktalarda değerlendirilememektedir. Halbuki turizmin ilçe için önemli bir istihdam sahası ve gelir kaynağı olabileceği aşikardır. İlçe turizmi sadece kültürel mirasla sınırlı kalmayacak olup doğa turizmi (Dağılcak Tabiat Parkı gibi), agro-turizm, yayla turizmi gibi turizmin pek çok kolundan kaynağından bulunmasından ötürü büyük bir potansiyeli haizdir. Bu çalışmada; Adana gibi iktisadi bakımdan Türkiye'nin önemli merkezlerinden birinin yüzölçümü açısından 1., nüfus miktarı açısından ise 6 . sırada yer alan Kozan ilçesi, nüfus coğrafyası özelinde irdelenmiştir. Çalışmada ilçenin toplam nüfus miktarı Osmanlı İmparatorluğu'nun son dönemi ile tüm Cumhuriyet Dönemi'ni kapsayacak şekilde ele alınmıştır. Bu kapsamda nüfusun cinsiyet yapısı ve medeni durumu, şehir ve kır nüfusları, eğitim durumu, nüfus yoğunlukları, coğrafi dağılım ve Adana ölçeğinde Kozan nüfusunun türlü açılardan yeri incelenmiştir. Buna göre de ilerleyen yıllarda demografik açıdan ortaya çıkabilecek durumlar, alınması gereken tedbirler, izlenebilecek yerel politikalar hakkında çıkarımlarda bulunulmuştur.

EXTENDED ABSTRACT: Kozan has become a part of the Fertile Crescent with its location, topographic, hydrographic and climatic features, and accordingly, it has been an important settlement whose history of civilization exceeds thousands of years. It should be underlined that Kozan, which has managed to preserve its political, religious, military, and economic importance in many periods of history, is a very special center not only from the point of Turkey but also from the history of world civilization. Known as "Sis" until the Republic Period, Kozan is today a district with a limited small and medium-sized industry that provides its living particularly with citrus fruits, horticulture, animal husbandry, and forestry largely in vegetative production. In Kozan, which we examined in terms of population characteristics, there are two periods that we can evaluate between 1927 1985 and 1990 - 2019. While the population in the district was increasing regularly and rapidly until 1985 after 1927, (following the departure of 
İmamoğlu) the population of the district started to increase at a much slower rate. The geographical conditions of the district have greatly influenced the settlement, development and population movements of this place. In Kozan, where characteristic Mediterranean climate prevails, factors such as the presence of marshes and the malaria epidemic that increases the severity of each summer, caused large masses of population to lead a nomadic life for a long time here. So much so that, even the notables of the region went to the plateaus in summer, but when the weather started to get colder, they returned to the plain area. Factors such as the drying of the swamps in the last years of the Ottoman Empire and the first years of the Republic Period, encouraging nomads to settled life and popularizing citrus agriculture have played a major role in the current socio-economic structure of Kozan. Addressing an area with certain borders with all kinds of demographic indicators, making healthy investments in that field in the short, medium and long term, provdes great benefit in terms of managing and directing resources (especially if the resources are limited) in a much healthier way. The analysis of the demographic structure of Kozan district, which we have examined completely in the scale of the Republic Period and partially in the last years of the Ottoman Empire, also enabled us to make certain inferences at this point. Considering only the development course of the population and the situation in recent years have revealed the following results:

- Kozan is approaching the level of developed countries in terms of age structure,

- District population is agig,

- It is observed that the people of Kozan generally do not leave the district / province,

- Employment and literacy of the female population is still negative compared to men,

- Still, the schooling rate of women has increased compared to the past and they are more involved in business life,

- Unregistered producers are still at a substantial level at the point of employment,

- Along with marriages, divorces have also increased significantly, and the number of single people generally tends to decrease,

- The population in the district displays a very unbalanced distribution,

- Compared to the past, the nomadic lifestyle has been abandoned to a great extent,

- Rural activities are still the most important source of income in the district,

Based on these inferences;

- Due to the aging of the district population, transportation, social services (such as patient care, home cleaning of the elderly, personal 
care), hobby facilities and other socialization structures should be established and / or arranged in Kozan,

- The sustainability of resources for local people, who mostly prefer to stay in Kozan, and effective management of resources for increasing demands are of great importance. Focus should be placed on investments in both economic and social terms,

- Studies should be initiated in the field of educational activities (Evening High Schools, Public Education Centers, etc.) in order to reduce the number of illiterate women,

- New employment areas for women should be created, especially the areas of use of the educated female population resource should be established. Investments for tourism and creating an employment area at the Kozan scale are considered very advantageous,

- A stricter recording and inspection mechanism should be established at the point of rural activities and the livelihood of the people there,

- Seasonal agricultural workers in Kozan should be organized in such a way that they will not cause any disturbance for both themselves and the local people during their temporary stay in the district,

- Considering the striking increase in divorces, expanding Family Counseling Centers by the local government and creating public service advertisements in order to direct them to these centers can be pointed out as the first step.

Planning of Kozan for a fully sustainable development in the field of transportation (such as Adana - Kozan - Kadirli - Osmaniye Railway Project), industry and agriculture, directing investments by considering the natural and cultural heritage of this place as a whole, is of great importance for the welfare level of the district population. The deep-rooted cultural heritage of the district is currently being evaluated very poorly at the point of tourism, and even not at some points. However, it is obvious that tourism can be an important employment area and source of income for the district. District tourism will not only be limited to cultural heritage, and it has a great potential due to its availability from many branches of tourism such as nature tourism (such as Dağılcak Nature Park), agro-tourism, plateau tourism. Adana is one of Turkey's leading economic centers. Kozan, on the other hand, ranks first in terms of area of this province and sixth in terms of population so the district is examined in terms of population geography. In the study, the total population amount of the district was handled in a way to cover the last period of the Ottoman Empire and the entire Republic Period. In this context, the gender structure and marital status of the population, urban and rural populations, educational status, population densities, geographical distribution and the location of the Kozan population in Adana scale were analyzed. Accordingly, inferences have been made about the demographic 
situations that may arise in the following years, the measures to be taken, and the local policies that can be followed. 